\title{
bastlot
}

\section{Sistema Proporcional Brasileiro e Lei 13165/2015: Um breve estudo sob o prisma da Qualidade da Democracia}

\author{
Polianna Pereira dos $\operatorname{Santos}^{1}$ (UFMG, Brasil) \\ poliannasantos@gmail.com \\ Procuradoria Regional Eleitoral, PRE/MG. \\ Av. Brasil, 1877- Funcionários \\ 30140002 - Belo Horizonte, MG - Brasil
}

1. Mestranda em Direito Político (UFMG). Especialista em Ciências Penais (IEC-PUC Minas). Professora de Graduação em Direito (UNIPAC - Itabirito) e de Pós-graduação lato sensu (PUC Minas). Assessora Jurídica da Procuradoria Regional Eleitoral de Minas Gerais. Membro-fundadora da Academia Brasileira de Direito Eleitoral e Político (ABRADEP) 


\title{
Resumo
}

A Lei 13165/2015 promoveu diversas modificações na legislação eleitoral, afetando, entre outros temas, a distribuição das cadeiras no sistema proporcional brasileiro a partir da exigência de percentual mínimo de votação nominal e modificação no cálculo de distribuição de vagas remanescentes. $O$ presente estudo tem a finalidade de analisar essas modificaçóes relacionadas ao sistema proporcional brasileiro sob a perspectiva da qualidade da democracia, além de testar possíveis efeitos da Minirreforma de 2015 a partir da comparação dos resultados obtidos em eleições anteriores com a antiga e a nova regulamentação legal.

Palavras chaves: Sistema proporcional. Qualidade da Democracia. Representação.

\section{Brazilian Proportional System and Law 13165/2015: A brief study under the perspective of the Quality of Democracy}

\begin{abstract}
Law 13165/2015 promoted several changes in the electoral legislation, affecting, amongst other themes, the distribution of chairs in the proportional system by requiring a minimum nominal voting percentage as well as changing the mathematics for the distribution of remaining seats. This study intends to analyze these changes, related to the Brazilian proportional system, under the perspective of the quality of democracy, while also testing possible effects of the legislative change by comparing results obtained in previous elections with both the old as the new legal regulations.
\end{abstract}

Keywordsः Proportional system. Quality of Democracy. Representation. 


\section{Introdução}

A Lei 13165 de 2015 promoveu profundas alterações na legislação eleitoral, com a finalidade declarada em sua ementa de "reduzir os custos das campanhas eleitorais, simplificar a administração dos Partidos Políticos e incentivar a participação feminina". Entre estas alterações está a modificação da forma de distribuição das cadeiras nas eleições segundo o Sistema Proporcional no Brasil, por meio da alteração dos artigos 108, 109 e 112 do Código Eleitoral.

Neste breve estudo serão analisadas essas modificações, as justificativas e os possíveis efeitos a serem observados nas próximas eleiçóes. Para tanto serão analisados, num primeiro momento, o Projeto de Lei 5735/2013, que culminou na promulgação da Lei 13165/2015, suas emendas e substitutivos.

Passa-se, na sequência, a uma breve revisão sobre sistemas eleitorais, especificamente sobre o sistema proporcional, seguida da comparação entre a sistemática verificada antes e após a modificação legislativa, a fim de delinear seus possíveis efeitos. Será considerada, ainda, a Ação Direta de Inconstitucionalidade (ADI 5420) proposta pelo Procurador Geral da República, apontando inconstitucionalidade dos incisos I a III do art. 109 do Código Eleitoral, com o texto alterado pela Lei 1365/2015 que modificou o cálculo da distribuição das sobras definindo um divisor fixo no modelo de distribuição por maiores médias e exigiu a verificação de um percentual mínimo de votação nominal para que os candidatos possam ocupar as vagas do partido na distribuição das vagas remanescentes.

A análise da modificação dos dispositivos legais indicados e de seus possíveis efeitos nas eleições vindouras será pautada na teoria da Qualidade da Democracia, especialmente tomando os parâmetros sugeridos por Diamond e Morlino ${ }^{400}$ (2004).

\section{Democracia e Participação}

Para proceder à análise das modificaçóes legislativas promovidas pela Minirreforma de 2015 no que diz respeito ao sistema proporcional brasileiro, faz-se necessário, discorrer sobre alguns conceitos básicos que serão tratados como premissas nesse estudo. É o caso da concepção de democracia adotada, compreensão de participação popular nesse contexto, bem assim a teorização de qualidade da democracia e os indicadores escolhidos para essa avaliação.

Não é tarefa simples conceituar democracia. Trata-se de conceito que variou largamente no tempo, e para o qual diversos estudiosos dedicaram tempo para teorizar. Simone GoyardFabre ${ }^{401}$, sobre esse aspecto, estatui:

O povo de Atenas cultuava a democracia e, ao mesmo tempo, Platão denunciava os seus perigos. O povo de Roma, nas palavras de Cícero e de Tácito, mais louvava as virtudes da República que prezava a democracia; mas sabia por experiência que tinha que lutar para ter acesso ao poder político, embora nunca tivesse a certeza de uma vitória

400. DIAMOND, Larry; MORLINO, Leonardo. The Quality of Democracy. CDDRL Working Papers, page 37.2004.

401. FABRE, Simone Goyard. O que é democracia. São Paulo: Martins Fontes, 2003, p. 341 
durável. No entanto, apesar da ambivalência que outrora acompanhou o surgimento das democracias originais, foi nela que a história do pensamento político foi buscar as máximas ordenadoras do ideal democrático que sempre se ergueu contra o inchaço de um poder tirânico: é preciso que o povo tenha liberdade de designar aqueles que o governam; é preciso que os governantes trabalhem sem se afastar da preocupação constante com a igualdade e a justiça, pelo bem de todos.

Robert Dahl procura delimitar em sua obra "Sobre a Democracia” o que é a democracia a partir da identificação de critérios de um processo democrático, observando que ao longo da história o conceito e os elementos necessários para a caracterização da democracia variaram largamente. Pensando, portanto, em uma "democracia ideal", o autor aponta cinco critérios a que um "processo para o governo de uma associação teria que corresponder, para satisfazer a exigência de que todos os membros estejam igualmente ${ }^{402}$ capacitados a participar nas decisões da associação sobre sua política": participação efetiva, igualdade de voto, entendimento esclarecido, controle do programa de planejamento ${ }^{403}$ e inclusão dos adultos ${ }^{404} 405$.

É característico da democracia - ou seu elemento para garantia da igualdade política que todo indivíduo (cidadão) é capaz, pelo menos, de definir o que é bom para si mesmo, e é isso que o qualifica para tomar decisóes políticas. Os gestores políticos devem ser dirigidos por quem tem capacidade de gestão, ou seja, a comunidade em condição de igualdade política. Essa igualdade política efetiva depende, sobremaneira, de virtude cívica, que é cultural, transmitida de geração em geração e pode ser obtida mediante educação cívica ${ }^{406}$. Segundo Dahl,“(...) um critério essencial para o processo democrático é a compreensão esclarecida: dentro de razoáveis limites de tempo, cada cidadão deve ter oportunidades iguais e efetivas de aprender sobre politicas alternativas pertinentes e suas prováveis consequências 407 ".

Essa aprendizagem vem com a ampliação da população alfabetizada, a oferta de informação obtida por fontes alternativas e independentes (liberdade de expressão e manifestação). Esses dados estão intrincados com a participação efetiva e a influência no planejamento político ${ }^{408}$.

402. DAHL (2001, P. 75-94) trabalha com a essencialidade do reconhecimento da igualdade política dos cidadãos para a compreensão da democracia. Afirma, inclusive, que a razão para "os direitos necessários a um processo de governo democrático" serem, necessariamente, "igualmente estendidos aos cidadãos" não é evidente, mas é "decisiva para a fé na democracia” (DAHL, 2001, P. 75).

403. Segundo o autor, com o controle do programa de planejamento de uma associação democrática deve estar nas mãos de seus membros, que "devem ter a oportunidade exclusiva para decidir como, e se preferirem, quais as questões que devem ser colocadas no planejamento" (DAHL, 2001, p.49).

404. DAHL, Robert A. Sobre a democracia. Brasília: Editora Universidade de Brasília, 2001, p. 49-50.

405. Numa democracia deve ser reconhecido ao maior número possível de pessoas o direito de cidadãos, de poder interferir na tomada de decisões, sem limitações como as havidas no século passado, referentes a critérios de renda ou formação para a obtenção de direitos políticos. Segundo o autor,"Todos, ou, de qualquer maneira, a maioria dos adultos residentes permanentes deveriam ter o pleno direito de cidadãos implícito no primeiro de nossos critérios [participação efetiva]” (DAHL, 2001, p.50).

406. As pessoas devem ser informadas para tomar decisões políticas (votar, acompanhar os governantes...).

407. DAHL, Robert A. Sobre a democracia. Brasília: Editora Universidade de Brasília, 2001, p. 204.

408. DAHL, Robert A. Sobre a democracia. Brasília: Editora Universidade de Brasília, 2001, p. 110-111. 
Carole Pateman, com a finalidade de encontrar o lugar da participação numa teoria da democracia moderna e viável, compara os estudos desenvolvidos por quatro grandes teóricos, após discorrer sobre a revisão realizada por Schumpeter do que ele chamou de Teoria Clássica da Democracia ${ }^{409}$ - Berelson, Dahl, Sartori e Ecksein. Com base nesses estudos, a autora identifica uma teoria democrática comum aos autores referidos - a que ela chama "teoria contemporânea da democracia":

Nessa teoria, a "democracia" vincula-se a um método político ou uma série de arranjos institucionais a nível nacional. O elemento democrático característico do método é a competição entre os líderes (elite) pelos votos do povo, em eleições periódicas e livres. As eleições são cruciais para o método democrático, pois é principalmente através delas que a maioria pode exercer controle sobre os líderes. A reação dos líderes às reivindicações dos que não pertencem à elite é segurada em primeiro lugar pela sanção da perda do mandato nas eleições; as decisões dos líderes também podem sofrer influências de grupos ativos, que pressionam nos períodos entre as eleições. (...) Finalmente, "participação", no que diz respeito à maioria, constitui a participação na escolha daqueles que tomam as decisões. Por conseguinte, a função da participação nessa teoria é apenas de proteção; a proteção do indivíduo contra as decisões arbitrárias dos líderes eleitos e a proteção de seus interesses privados. É na realização desse objetivo que reside a justificação do método democrático ${ }^{410}$.

Desse modo, seria possível que considerando o mínimo de convergência conceitual em uma teoria democrática contemporânea, a participação popular estaria situada, pelo menos, na escolha dos representantes pelo povo. Esse conceito é essencial para o presente estudo, eis que interessa identificar como se dá essa participação do eleitor na escolha dos seus representantes no sistema proporcional brasileiro, sobremaneira após as modificaçóes promovidas pela Lei 131656/2015.

\section{Qualidade da Democracia}

Diamond e Morlino desenvolveram uma linha metodológica, dentro da teoria da qualidade da democracia, que tem como pressuposto o fato de que aprofundar os estudos sobre democracia é um imperativo, e que reformas para melhorar a qualidade da democracia são essenciais, mesmo para democracias estabilizadas. Para trabalhar com a concepção de qualidade da democracia, delimitam cinco dimensóes conceituais mínimas - que não constituem totalmente a democracia, mas que são imprescindíveis: liberdade, Estado de Direito, Accountability vertical, responsividade e igualdade.

Além disso, definem democracia a partir de quatro requisitos: (a) sufrágio universal adulto, (b) eleiçóes recorrentes, livres, competitivas e justas, (c) mais de um partido sério e (d)

409. Carole Pateman (PATEMAN, Carole. Participação e teoria democrática. Paz e Terra, 2003, p. 28/29) entende que a noção de uma Teoria Clássica da Democracia é um mito.

410. PATEMAN, Carole. Participação e teoria democrática. Paz e Terra, 2003, p. 25 
fontes alternativas de informação. Para a análise da qualidade da democracia, compreendem qualidade com significado de procedimento, de conteúdo e de resultado, de forma que, uma democracia de boa qualidade satisfaz as expectativas dos eleitores sobre governança (qualidade em termos de resultado); os cidadãos, associações e a comunidade aproveitam extensa liberdade e igualdade política (qualidade em termos de conteúdo); e os cidadãos tem soberania para que possam, eles mesmos, avaliar se o governo provê liberdade e igualdade de acordo com o Estado de Direito (qualidade em termos de procedimento) ${ }^{411}$.

A partir desses preceitos, os autores sugerem oito dimensóes em que as democracias variam em qualidade - que podem, por essa razão, ser utilizados como indicadores para avaliação da qualidade da democracia nas sociedades, divididos em dimensões procedimentais, substanciais, e uma ligação entre as duas primeiras.

São consideradas dimensões procedimentais (princípios concernentes a regras e práticas): o Estado de Direito (Rule Of Law), a Participação, a Competição, o Accountability vertical e o Accountability horizontal. As dimensões substanciais são o respeito por liberdades civis e políticas, e a progressiva implementação de maior igualdade política (social e econômica). Por fim, fazendo um link entre as dimensóes procedimentais e substanciais, a Responsividade.

Para o presente estudo merecem destaque, de forma mais específica, os indicadores de participação e Accontability vertical.

Para os autores nenhum regime pode ser considerado democrático a menos que assegure a todos os adultos direitos de participação política, incluindo direito ao voto. Para além de um critério mínimo para definição da democracia, destaca-se que maior é a qualidade da democracia quanto maiores forem as garantias para a ampla participação popular, incluindo, além do direito de voto, o direito de reunião, de protesto e de buscar por seus interesses, participação em partidos políticos, de discussóes publicas, demandando prestação de contas de seus representantes, entre outros.

Veja-se, nesse aspecto, o direito do voto para definição dos representantes é requisito para democracia e primeiro passo para identificação de uma boa democracia. Para dar suporte a esse requisito/dimensão da qualidade da democracia, a cultura política exerce um papel muito importante, assim como a difusão da educação básica e mesmo a alfabetização.

Os autores destacam ainda uma forma comum de subversão da participação, que passa pela apatia dos cidadãos que duvidam da eficácia dos mecanismos democráticos ou se tornam alienados do processo democrático como resultado da baixa qualidade da democracia em outros aspectos - corrupção, por exemplo ${ }^{412}$.

Utilizando a nomenclatura sugerida por Paola Novaes Ramos ${ }^{413}$, podemos reunir essa ausência de participação, especificamente no que concerne ao direito de voto, no conceito de alheamento eleitoral. A expressão engloba votos em branco, nulos e abstenções, que podem

411. DIAMOND, Larry; MORLINO, Leonardo. The Quality of Democracy. CDDRL Working Papers, page 37.2004, p 4-5.

412. DIAMOND, Larry; MORLINO, Leonardo. The Quality of Democracy. CDDRL Working Papers, page 37.2004, p. 11.

413. RAMOS, Paola Novaes. Alheamento eleitoral: reflexóes sobre o significado de votos embranco, votos nulos e abstenções na teoria política contemporânea. Mediações-Revista de Ciências Sociais, v. 14, n. 1, p. 170-199, 2009. 
ter diversos significados, entre os quais o apontado descrédito no processo democrático, ou mesmo uma incompreensão por parte do eleitorado.

A questão atinente à incompreensão pelo eleitorado, de forma muito específica, pode ser identificada no sistema proporcional brasileiro, por diversas razões, e as modificações legislativas realizadas não parecem melhorar as perspectivas para sua compreensão. $\mathrm{Na}$ verdade, os arranjos institucionais que estão contidos no sistema proporcional brasileiro dificultam não só a compreensão do sistema, como também o devido direcionamento do voto pelo eleitor melhor informado, participativo e consciente.

Para possibilitar a participação efetiva é necessário que os adultos tenham acesso a informações, claras, completas e corretas, e tenham condições de interferir na definição dos seus representantes e na formação da pauta de discussões. A formação de coligações dificulta a participação popular já no momento do voto, no sistema proporcional, pois não há possibilidade de o eleitor direcionar minimamente o partido que será beneficiado por seu voto. Qualquer partido coligado poderá ser beneficiado, o que causa estranhamento quando se pensa que o voto de legenda é justificado pela ideologia partidária. Sobre essa peculiaridade, Jairo Nicolau ${ }^{414}$ pondera:

A combinação de coligação com a possibilidade de o eleitor votar na legenda, tal como ocorre no Brasil, produz um resultado curioso. Ao votar na legenda, quando o partido de sua preferência está coligado, o eleitor não garante que seu voto ajude a eleger especificamente um nome do seu partido. Na prática, esse voto é contabilizado apenas para definir o total de cadeiras obtido pela coligação.

Isso impede, ou dificulta, sobremaneira, o Accoutability Vertical, relacionado a participação por meio do voto. Guillermo O'Donnel afirma que representação implica a ideia de prestação de contas. Segundo o autor:

Representation entails accountability: somehow representatives are held responsible for their actions by those they claim to be entitled to speak for. In institutionalized democracies, accountability runs not only vertically, making elected officials answerable to the ballot box, but also horizontally, across a network of relatively autonomous powers (i.e., other institutions) that can call into question, and eventually punish, improper ways of discharging the responsibilities of a given official. Representation and accountability entail the republican dimension of democracy: the existence and enforcement of a careful distinction between the public and the private interests of office holders ${ }^{415}$.

O Accountability, essa prestação de contas dos atos dos representantes eleitos, pode ser realizado pelos cidadãos, os próprios eleitores (accontability vertical), na escolha/ manutenção dos representantes eleitos; e realizado por instituições políticas, órgãos de fiscalização, Ministério Público, entre outros (accontability horizontal).

Na primeira espécie - accontability vertical - os eleitores têm em suas mãos o peso do voto, e por meio da avaliação das propostas, vida pregressa, exercício em cargos eletivos anteriores, ou qualquer que seja a razão, optam por votar ou não votar em determinado candidato

414. NICOLAU, Jairo Marconi. Sistemas eleitorais. EDITORA FGV, 2004, p. 54.

415. O’DONELL, Guillermo A. Delegative democracy. Journal of democracy, v. 5, n. 1, p. 55-69, 1994, p. 61. 
ou partido. Nesse caso, a sanção que pode ser aplicada é o insucesso na eleição, ou a não reeleição, em vista, por exemplo, do não cumprimento de propostas ou da atuação dos representantes nos cargos eletivos correspondentes. No accontability horizontal, por outro lado, sanções institucionalizadas podem ser aplicadas - multas, obrigação de devolução de valores, privação da liberdade, inelegibilidades, entre outras.

Sobre o Accoutability vertical, Diamond e Morlino esclarecem:

The electoral form of vertical accountability has a periodic nature and is dependent on the various local and national election dates. Ideally, the performance of the incumbent is reviewed and evaluated, policy alternatives are debated, and the vote either rewards the incumbent party and office-holders or punishes them by voting for an opposition party (or abstaining from the vote). As Schmitter notes, the outcome of accountability may just as likely be reward (reelection) as punishment (defeat), for the most accountable leaders are really those whose conduct and decisions conform to citizen expectations (and the law). The dynamics of vertical accountability extend beyond elections and the interplay between voters and their elected representatives, however, encompassing as well the efforts of civic associations, NGOs, social movements, think tanks, and the mass media to hold government accountable in between elections ${ }^{416}$.

O fato de o eleitor não conseguir, no sistema proporcional brasileiro, determinar de forma clara a quem vai privilegiar com seu voto, dificulta a realização do accontability vertical. Isso porque, ainda que tenha pretensão de 'punir' algum candidato direcionando o voto a outro candidato ou a outro partido, pode acabar favorecendo-os.

A partir dessas balizas teóricas, passa-se à análise das alterações promovias pela Lei $13165 / 2015$ no sistema proporcional brasileiro.

\section{Minirreforma eleitoral de 2015: a Lei 13165}

A Lei 13165/2015 foi promulgada num momento de furor político, aparecendo de certa forma como resposta às manifestações populares de junho de 2013 no Brasil. Essas manifestações tiveram como marco inicial a discussão sobre aumento de tarifas de transporte público em São Paulo, e com o passar dos dias, da repercussão e da repreensão policial sofrida passou a representar diversas bandeiras em todo território brasileiro, tais como a Copa do Mundo de 2014 no Brasil e os gastos públicos realizados com essa finalidade, corrupção, entre outros, e marcaram um desprestígio da classe política com o seu eleitorado ${ }^{417}$.

\footnotetext{
416. DIAMOND, Larry; MORLINO, Leonardo. The Quality of Democracy. CDDRL Working Papers, page 37.2004, p. 14.

417. A referência às manifestações populares de 2013 no Brasil é utilizada neste breve estudo apenas para fins de contextualização. Sobre o tema, sugere-se a leitura do texto "Brasil, Manifestações Populares e Grandes Eventos: Questões de (In)Segurança e Imagem Internacional”, de Bernardo Wahl G. de Araújo Jorge (JORGE, Bernardo Wahl G. de Araújo. "Brasil, Manifestações Populares e Grandes Eventos: Questões de (In)Segurança e Imagem Internacional. Revista Mundorama, 2013.).
} 
Em 21 de junho de 2013 a Presidente Dilma Roussef fez um pronunciamento em cadeia nacional de rádio e televisão, sobre as manifestaçóes populares, e entre outros tópicos abordados, destacou a importância de realizar reforma política:

Quero contribuir para a construção de uma ampla e profunda reforma política, que amplie a participação popular. É um equívoco achar que qualquer país possa prescindir de partidos e, sobretudo, do voto popular, base de qualquer processo democrático. Temos de fazer um esforço para que o cidadão tenha mecanismos de controle mais abrangentes sobre os seus representantes ${ }^{418}$.

O momento político foi oportuno para as modificações, mas o Projeto de Lei que culminou com a promulgação da Lei 13165/2015 foi apresentado em junho de 2013, pouco antes do ápice das manifestações populares. O PL 5735/2013 recebeu 135 emendas antes de a Lei $13165 / 2015$ ser promulgada. O Projeto original e suas alterações serão considerados, neste momento, nos pontos de interesse do presente estudo. Destacam-se, portanto, as alteraçóes e proposições relacionadas à distribuição das cadeiras nas eleições proporcionais.

A versão original do PL 5735/2013 não previa alterações ao arts. 108, 109 e 112 do Código Eleitoral ${ }^{419}$. A Justificativa da primeira versão apresentou como premissas que balizaram o projeto: a) simplificar, desburocratizar e dar transparência ao processo eleitoral; b) evitar a judicialização excessiva do processo eleitoral; c) fortalecer a participação popular no processo eleitoral ${ }^{420}$.

Em nenhum momento da justificativa foram levantadas questões específicas sobre a necessidade de alterar o processo de distribuição de cadeiras no sistema proporcional, ou mesmo sua modificação em outros âmbitos. O Projeto recebeu 135 emendas $^{421}$. Dentre as 34 Emendas Aglutinativas de Plenário (EMA) apresentadas na Câmara, nenhum tópico referente à distribuição das cadeiras no sistema proporcional foi tratado. Os temas recorrentes nessas emendas são propaganda eleitoral, financiamento de campanha e voto em trânsito.

418. Disponível em: <http://www2.planalto.gov.br/acompanhe-o-planalto/discursos/discursos-da-presidenta/pronunciamento-da-presidenta-da-republica-dilma-rousseff-em-cadeia-nacional-de-radio-e-tv>. Acesso em: 10/01/2016.

419. O texto original está disponível para consulta no sítio eletrônico da Câmara dos Deputados, com as informações sobre Projetos de Leis e outras Proposições.

420. O texto original está disponível para consulta no sítio eletrônico da Câmara dos Deputados, com as informações sobre Projetos de Leis e outras Proposições. Disponível em:<http://www2.camara.leg.br/ proposicoesWeb/prop_mostrarintegra;jsessionid=0E17BF9F7B26C75690B768C58D337BED.proposico esWeb2? codteor $=1102056 \&$ filename $=P L+5735 / 2013>$. Acesso em 10/01/2016.

421. Todas estão disponíveis no sítio eletrônico da Câmara dos Deputados, entre Projetos de Leis e outras Proposições. 
Entre as 98 Emendas de Plenário (EMP), somente duas trataram do tema: EMP 79 e 80. Na verdade, ambas se limitaram a propor supressão (EMP 79422) ou alteração (EMP $80423)$ do $\$ 2^{\circ}$ do art. 109 , CE, que trata da distribuição das sobras e estabelece que somente possam participar os partidos que tenham atingido o quociente partidário. As Emendas de Plenário referidas sugeriam que todos os partidos que concorreram as eleições, independentemente de terem atingido o quociente eleitoral deveriam participar da distribuição das vagas não preenchidas pelo quociente partidário.

A Subemenda Substitutiva de Plenário (SSP1) de 09/07/2015 trata, pela primeira vez, da exigência de um percentual mínimo de votação nominal para os candidatos que concorrem às eleições proporcionais, sem, contudo, conter em seu texto qualquer justificativa para tais modificações. A SSP1 sugere a alteração do art. 108 do Código Eleitoral, que passaria a dispor:

Art. 108. Estarão eleitos, entre os candidatos registrados por um partido ou coligação que tenham obtido votos em número igual ou superior a $10 \%$ (dez por cento) do quociente eleitoral, tantos quantos o respectivo quociente partidário indicar, na ordem da votação nominal que cada um tenha recebido.

Parágrafo único. Os lugares não preenchidos em razão da exigência de votação nominal mínima a que se refere o caput serão distribuídos de acordo com as regras do art. $109^{424}$.

A Emenda/Substitutivo do Senado (EMS), de 08/09/2015, inclui no PL 5735 as alterações referentes à complexa divisão das vagas no sistema proporcional, alterando os arts. 108 , 109, 111 e 112 do Código Eleitoral. No que tange à alteração promovida pela SSP1, no art. 108, o Substitutivo do Senado sugere a alteração de 'coligações' por 'federações' ${ }^{\text {'25 }}$, e propõe a

422. EM 79: Suprima-se o $\$ 2^{\circ}$ do art. 109 da lei no. 4.737 de 25 de julho de 1965, modificada pelo art. $5^{\circ}$ fo substitutivo ao projeto de lei 2.259 de 2015. Justificativa: A distribuição dos lugares, pelo sistema atual, distorce o resultado eleitoral, permitindo que candidatos menos votados assumam as vagas das "sobras". A possibilidade de que todos os partidos concorram, independentemente de terem obtido o quociente eleitoral reflete melhor o resultado das urnas. 09/07/2015.

423. EM 80: Acrescente-se ao art. $5^{\circ}$ do Substitutivo aos Projetos de Lei nos 5.735/2013, 2.078/2015 e $2259 / 2015$ o seguinte dispositivo, alterando o $\$ 2^{\circ}$, do art. 109, da Lei 4.737, de 25 de julho de 1965 - Código Eleitoral:

"Art. 109

$\$ 2^{\circ}$ - Poderão concorrer à distribuição dos lugares não preenchidos todos os Partidos e coligações, mesmo aqueles que não tiverem obtido o quociente eleitoral." (NR)

Justificativa: A exclusão de partidos e coligações que não obtiveram o quociente eleitoral fere o princípio da eleição proporcional para a Câmara dos Deputados, Assembleias Legislativas e Câmaras Municipais. Para corrigir tal distorção, estamos apresentando a presente emenda, esperando poder contar com o apoio dos nossos pares. 09/07/2015.

424. Disponível em: <http://www2.camara.leg.br/proposicoesWeb/prop_mostrarintegra?codteor= 1359713\&filename $=S S P+1+\% 3 D \% 3 E+P L+5735 / 2013>$. Acesso em: 09/01/2016

425. Não se trata, por certo, de mera terminologia. O Senado sugeriu a adoção de federação de partidos no lugar de coligações. Não obstante, esse tema não será objeto de investigação aprofundada nesse estudo, sobremaneira porque a proposta não foi aprovada, e a Lei 13165/2015 ainda manteve o sistema de coligaçóes vigente. A Câmara dos Deputados publicou no Câmara Notícias em 05/07/2005 em seu sítio eletrônico, a seguinte definição para federação de partidos: "Sistema proposto para substituir as coligações partidárias nas eleições proporcionais (para vereador, deputado estadual e deputado federal). A federação permite que os partidos com maior afinidade ideológica e programática se unam para atuar de maneira uniforme em todo 
modificação dos arts. 109, 111 e 112:

Art. 109. Os lugares não preenchidos com a aplicação dos quocientes partidários e em razão da exigência de votação nominal mínima a que se refere o art. 108 serão distribuídos de acordo com as seguintes regras:

I - dividir-se-á o número de votos válidos atribuídos a cada partido ou federação pelo número de lugares definido para o partido pelo cálculo do quociente partidário do art. 107, mais 1 (um), cabendo ao partido ou federação que apresentar a maior média um dos lugares a preencher, desde que tenha candidato que atenda à exigência de votação nominal mínima;

II - repetir-se-á a operação para cada um dos lugares a preencher;

III - quando não houver mais partidos ou federações com candidatos que atendam às 2 (duas) exigências do inciso I, as cadeiras serão distribuídas aos partidos que apresentem as maiores médias.

$\S 1$ o O preenchimento dos lugares com que cada partido ou federação for contemplado far-se-á segundo a ordem de votação recebida por seus candidatos.

$\S 2$ o Somente poderão concorrer à distribuição dos lugares os partidos ou as coligações que tiverem obtido quociente eleitoral." (NR)

Art. 111. Se nenhum partido ou federação alcançar o quociente eleitoral, considerar-se-ão eleitos, até serem preenchidos todos os lugares, os candidatos mais votados (NR)

"Art. 112.

I - os mais votados sob a mesma legenda ou federação e não eleitos efetivos das listas dos respectivos partidos ou federações;

Parágrafo único. $\mathrm{Na}$ definição dos suplentes da representação partidária, não há exigência de votação nominal mínima prevista pelo art. 108." (NR ${ }^{426}$

O Substitutivo do Senado, assim como a Subemenda Substitutiva do Plenário, não contém, em seu texto principal, justificativas para as modificações propostas. No Parecer proferido ao Substitutivo do Senado Federal ao PL 5735/2013 apresentado em 09/09/2015 427 optou-se pela rejeição de emendas que, entre outros temas, versassem sobre federação partidária e esvaziamento das coligações. Foram aprovadas, nesse documento, as alterações propostas aos arts. 109 e parágrafo único do art. 112, com a substituição do termo "federação" por "coligação"; e rejeitados as alterações aos arts. 108 e 112.

$\mathrm{Na}$ verdade, em consulta aos documentos disponibilizados no sítio eletrônico da Câmara dos Deputados sobre a tramitação do PL 5735/2013 e da promulgação da lei não foram localizados textos que aprofundassem o debate sobre a importância/necessidade de modificar os dispositivos do Código Eleitoral no que concerne à distribuição de vagas obtidas nas eleições

o País e, ao mesmo tempo, contribui para que os pequenos partidos ultrapassem a cláusula de barreira. Ela funciona como uma forma de agremiação partidária, formada até quatro meses antes das eleições. Durante três anos, eles deixarão de atuar como partidos isolados e passarão a agir como se fossem um único partido". (Câmara dos Deputados, 2005)

426. Disponível em: < http://www2.camara.leg.br/proposicoesWeb/prop_mostrarintegra;jsessionid $=821 \mathrm{AF} 6 \mathrm{E} 8 \mathrm{~A} 8 \mathrm{D} 46 \mathrm{~B} 11531494 \mathrm{~A} 238603089$. proposicoes Web2? codteor $=13825928$ filename $=\mathrm{EMS}+57$ 35/2013+\%3D\%3E+PL+5735/2013 >. Acesso em 10/01/2016

427.Disponível em: < http://www2.camara.leg.br/proposicoesWeb/prop_mostrarintegra?codteor= $1383612 \&$ filename $=P S S+1+C C J C+\% 3 D \% 3 E+P L+5735 / 2013>$. Acesso em 10/01/2016. 
proporcionais. O fato é que a minirreforma de 2015 envolveu temáticas das mais diversas, e sua aprovação foi realizada com relativa urgência, ante a finalidade de aprovar as modificaçóes em tempo hábil para que pudessem ser aplicadas já nas eleições seguintes, de 2016, em atenção ao princípio da anualidade eleitoral, conforme disposto no art. 16 da Constituição da República ${ }^{428}$.

Em estudos anteriores à Minirreforma de 2015, Carlos Ranulfo Melo, analisando o tema reforma política em perspectiva comparada na América do Sul, pontuou que o Brasil - juntamente com o Chile - seria um dos países com maiores dificuldades de implementar de fato reforma política. Destacou, contudo duas agendas de reforma, uma das quais estaria centrada no aperfeiçoamento da representação proporcional no Brasil. $\mathrm{O}$ autor destaca que

(...) a ocorrência de um processo de reforma política depende de como se combinam pressões sociais e constituição de maiorias legislativas. A depender de como isso se dá, as reformas podem ser bem sucedidas, ainda que os objetivos imediatos dos reformadores sejam suplantados pela dinâmica política, fracassar completamente em seus objetivos ou simplesmente não acontecer ou fazê-lo de forma muito limitada ${ }^{429}$.

A Minirreforma de 2015 segue um padrão de alteraçóes pontuais na legislação eleitoral, mas neste momento, é possível reconhecer a existência de pressóes sociais decorrentes das manifestações populares de 2013. A Minirreforma, aprovada com alguma urgência, não necessariamente incluindo a participação de setores da sociedade interessados em pautar a Reforma Política, se nos apresenta como uma colcha de retalhos, que pode eventualmente receber críticas por falta de sistematicidade. Essa crítica, contudo, demandaria estudos mais amplos, que não serão desenvolvidos nesse trabalho.

A análise das alteraçôes promovidas pela Lei 13165/2015 nesse estudo será limitada às questóes atinentes à distribuição das cadeiras no sistema eleitoral. Verificou-se, pois, que o projeto original não continha qualquer previsão nesse sentido, que foram incluídas especialmente nos últimos substitutivos sem um texto de justificação. Antes, contudo, de conhecer essas alterações na norma no sistema proporcional, serão feitos breves considerações sobre os sistemas eleitorais, a fim de contextualizar a questão.

428. De acordo com o art. 16, CR, "A lei que alterar o processo eleitoral entrará em vigor na data de sua publicação, não se aplicando à eleição que ocorra até um ano da data de sua vigência". A jurisprudência mais recente entende que o processo eleitoral tem início no prazo para a definição de domićlío eleitoral e filiação partidária. Apesar de a novel lei ter modificado esse prazo com relação à filiação partidária seis meses antes da data do pleito - o prazo para a definição do domicílio eleitoral permanece inalterado - um ano antes da data do pleito.

429. MELO, Carlos Ranulfo, Reforma Política em Perspectiva Comparada na América do Sul. p. 45-62. In. AVRITZER, Leonardo; ANASTASIA, Fátima (Ed.). Reforma política no Brasil. Editora UFMG, 2007, p. 61. 


\section{Sistemas eleitorais - breves apontamentos}

Michael Gallagher , ao destacar a importância do tema sistemas eleitorais, esclarece que eles fazem a conexão entre as preferências dos cidadãos e as decisóes políticas dos governantes. Segundo o autor,

By an electoral system we mean the set of rules that structure how votes are cast at elections for a representative assembly and how these votes are then converted into seats in that assembly. Given a set of votes, an electoral system determines the composition of the parliament (or assembly, council, and so on as the case may be). The electoral system is narrower than what we term electoral regulations, by which we mean the wider set of rules concerning elections. Such rules-concerning, for example, ease of access to the ballot for would-be candidates, the right to vote, the fairness of the administration of the election, the transparency of the counting of the votes-are all very important in determining the significance and legitimacy of an election ${ }^{430}$.

Tavares ${ }^{41}$ aponta para a existência de três grandes temas que estão vinculados à definição e compreensão dos sistemas eleitorais: teoria da representação política, normas, instituiçôes e mecanismos técnicos que constituem o sistema e funções e potencial estratégico do sistema.

Jairo Nicolau ${ }^{432}$ esclarece que sistema eleitoral é "(...) o conjunto de regras que define como em uma determinada eleição o eleitor pode fazer suas escolhas e como os votos são contabilizados para serem transformados em mandatos (cadeiras no Legislativo ou chefia do Executivo)".

De formas diferentes os doutrinadores identificam a complexidade e a relevância do tema. A representação política varia em conformidade com o sistema adotado - seja na definição das candidaturas e campanhas, de forma prévia, seja na escolha dos eleitores, e a posteriori, na atuação política dos eleitos. A definição do sistema eleitoral gera grande impacto no exercício da democracia, especificamente na democracia representativa.

Nas palavras de Paulo Bonavides 433 "o sistema eleitoral adotado num país pode exercer - e em verdade exerce - considerável influxo sobre a forma de governo, a organização partidária e a estrutura parlamentar, refletindo até certo ponto a indole das instituiçôes e a orientação política do regime".

430. GALLAGHER, Michael; MITCHELL, Paul (Ed.). The politics of electoral systems. Oxford: Oxford University Press, 2005, p. 3.

431. TAVARES, José Antônio Giusti. Sistemas Eleitorais nas Democracias Contemporâneas.Teoria, instituições, estratégia. Rio de Janeiro: Relume-Dumará, 1994, p. 17.

432. NICOLAU, Jairo Marconi. Sistemas eleitorais. EDITORA FGV, 2004, p. 10.

433. BONAVIDES, Paulo. Ciência política. São Paulo: Malheiros, 2012, p. 265. 
É possível indicar algumas variáveis relevantes ${ }^{434}$ na definição e diferenciação dos sistemas eleitorais: a magnitude ${ }^{435}$ da circunscrição ${ }^{436}$ e sua distribuição geográfica ${ }^{437}$; a forma de apresentação das candidaturas (pessoal ${ }^{438}$ ou pelos partidos políticos ${ }^{439}$ ); a modalidade do voto e a fórmula eleitoral adotada ${ }^{440}$. Eneida Desiree Salgado, discorrendo sobre as formulas eleitorais, esclarece:

(...) há uma pluralidade de fórmulas eleitorais e inúmeras variações em seu desenho. No entanto, é possível classificar as fórmulas eleitorais a partir de seu princípio fundamental, e assim apresentar aquelas que se baseiam no princípio majoritário, aquelas que se relacionam à representação proporcional e, finalmente, as que buscam a combinação de ambos os princípios ${ }^{441}$.

Aponta-se para a existência de duas grandes famílias de sistemas eleitorais: o majoritário e o proporcional. Em decorrência da junção de algumas de suas características surge o modelo misto. Contudo, é relevante notar que cada país, ao adotar tal ou qual modelo, adéqua-o à suas realidades políticas e contingenciais, de modo que é possível afirmar que há tantos sistemas eleitorais quantos são os países.

434.Trata-se de variáveis apresentadas por Eneida Desiree, citando Luis Virgílio Afonso da Silva (SILVA, Luis Virgílio Afonso da. Sistemas eleitorais: tipos, efeitos jurídico-políticos e aplicação ao caso brasileiro. São Paulo: Malheiros, 1999, p. 41). Ainda é possível acrescentar a esta lista alguns elementos importantes para a compreensão e diferenciação dos sistemas eleitorais: barreira eleitoral, influência das eleições presidenciais sobre as legislativas, vínculos eleitorais interpartidários, entre outros.

435. Magnitude, representado pela sigla "M" diz respeito à quantidade de mandatos a serem definidos em cada circunscrição. Diferencia, basicamente, distritos uninominais, em que se pretende eleger apenas um representante, de modo que a magnitude é igual a um $(M=1)$, e distritos plurinominais, em que se pretende eleger mais de um representante $(M>1)$.

436. Considerando circunscrição divisão eleitoral do espaço territorial, em vistas da realização do pleito. $\mathrm{O}$ termo varia entre os países, e diversos autores - como exemplo, Jairo Nicolau - optam por utilizar o termo "distrito" para indicar essa divisão geográfica. Adota-se, por convenção, o termo "circunscrição" ao tratar-se de sistemas majoritários e proporcionais, e "distrito", ao tratar-se de sistemas mistos ou distritais.

437. A forma que esses mandatos serão distribuídos na circunscrição e a definição geográfica dessas circunscrições também são relevantes. O ideal, num ambiente democrático, é que estes desenhos sejam previamente realizados, de forma isenta de interesses políticos partidários. O desenho, ou o formato dessa repartição geográfica poderia, eventualmente, ser modelado para atender interesses de grupos políticos. Deve-se excluir, portanto, a possibilidade de ocorrência de distritalização tendenciosa, como na forma conhecida nos Estados Unidos por gerrymandering (termo cunhado em razão de prática que acontecia nos EUA, com a definição periódica dos distritos, que eventualmente poderia ocorrer com a finalidade de obter vantagens na eleição de representantes políticos de determinado grupo. Por volta de 1812 a lei de Massachusetts, Estado governado por Elbridge Gerry, redesenha os limites territoriais e cria figuras disformes, semelhante a uma salamandra (em inglês salamander). Os novos círculos eleitorais foram denominados, pelos jornalistas da época, de "Gerry-mander")

438. Denominado lista aberta ou panaches.

439.Denominado listas fechadas, em que há um monopólio dos partidos políticos em apresentar candidatos.

440. É neste aspecto, sobremaneira, que a minirreforma de 2015 afeta o sistema proporcional brasileiro.

441. SALGADO, Eneida Desiree. Sistemas Eleitorais: experiências iberoamericanas e características do modelo brasileiro. Coordenadora Eneida Desiree Salgado. Belo Horizonte: Fórum, 2012, p. 149. 
O Brasil adota os sistemas majoritário e proporcional. O primeiro, para os cargos do Poder Executivo, e para o Senado Federal. O sistema proporcional é observado para os demais cargos do Poder Legislativo.

Pelo sistema majoritário, são eleitos os candidatos que obtiverem mais votos. É o sistema mais simples. Os eleitores escolhem os seus candidatos e votam nominalmente. $\mathrm{Na}$ eleição de presidente da República, governador e prefeitos - nos municípios com mais de 200.000 eleitores - realiza-se segundo turno quando nenhum candidato obtém a maioria absoluta (mais de $50 \%$ dos votos, não considerados os brancos e nulos). Nos demais casos - senadores e prefeitos de municípios com menos de 200.000 eleitores -, são eleitos os candidatos mais votados (maioria simples).

O sistema proporcional é mais complexo. No modelo adotado no Brasil para a maioria dos cargos do Poder Legislativo ${ }^{442}$ o eleitor escolhe seu candidato entre aqueles apresentados em lista não ordenada ${ }^{443}$ por um Partido Político ou uma Coligação. Os eleitores no Brasil podem optar por votar nominalmente em seu candidato ${ }^{444}$, ou somente na legenda partidária. Os partidos podem ainda se coligar, sem obrigatoriedade de vinculação entre as candidaturas em âmbito nacional, estadual, distrital ou municipal (EC52/2006, art. 17, $₫ 1^{\circ} \mathrm{CR} / 88^{445}$ ). As coligaçôes formadas apresentam lista conjunta de candidatos, e o cálculo do quociente eleitoral é feito com base nos votos obtidos pela coligação ${ }^{446}$.

A distribuição das cadeiras no sistema proporcional foi modificada pela novel lei, e será objeto de analise mais detalhada nos tópicos seguintes.

442. À exceção da eleição dos membros do Senado, que conforme dispóe o Art. 83, do Código Eleitoral: “Art. 83. Na eleição direta para o Senado Federal, para Prefeito e Vice-Prefeito, adotar-se-á o princípio majoritário".

443. Significa dizer que no sistema proporcional adotado no Brasil os partidos ou Coligações não estabelecem uma ordem de candidatos que serão diplomados. Os eleitores podem votar livremente em seus candidatos, e é o voto nominal por eles recebido que definirá a ordem da diplomação. Com a alteração promovida pela Lei 13165/2015, essa votação nominal definirá, ainda, a possibilidade de ocupar as cadeiras obtidas pelo partido ou não.

444. Os eleitores votam em um candidato apenas, por isso a denominação lista aberta uninominal.

445. § $1^{\circ}$ É assegurada aos partidos políticos autonomia para definir sua estrutura interna, organização e funcionamento e para adotar os critérios de escolha e o regime de suas coligações eleitorais, sem obrigatoriedade de vinculação entre as candidaturas em âmbito nacional, estadual, distrital ou municipal, devendo seus estatutos estabelecer normas de disciplina e fidelidade partidária. (Redação dada pela Emenda Constitucional $n^{\circ}$ 52, de 2006).

446. Somando-se aqueles obtidos por todos os seus candidatos e aqueles obtidos pelos partidos, considerando a possibilidade de voto em legenda. Importa ressaltar que a formação de legenda não implica na criação de uma nova legenda para a Coligação, com um número próprio. $\mathrm{O}$ eleitor pode escolher votar na legenda de um dos partidos que compóem a Coligação, e seu voto será somado aos demais para definição do quociente eleitoral e partidário. 


\section{Distribuição das cadeiras antes da Minirreforma de 2015}

A contabilização dos votos no sistema proporcional adotado pelo Brasil e sua transformação em vagas nas Casas Legislativas ocorre em etapas. Calcula-se, primeiramente, o quociente eleitoral (art. 106, do Código Eleitoral ${ }^{447}$ ), na sequencia, o quociente partidário (art. 107, do Código Eleitoral ${ }^{448}$ ) e faz-se, conforme seja necessária, a repartição dos restos eleitorais (art. 109, Código Eleitoral ${ }^{449}$ ).

As modificações realizadas pela Lei 13165/2015 não alteram completamente essa ordem, mas a sua sistemática. Nesse tópico será detalhada a forma em que essa distribuição era realizada antes da reforma. Há que se destacar, contudo, que alguns pontos permanecem inalterados, o que será mais bem detalhado no tópico seguinte, que especifica as alteraçóes.

No sistema proporcional somente o partido - ou Coligação - que atingir um número mínimo de votos tem o direito a obter vaga na casa legislativa. Esse "número mínimo de votos" é obtido por meio do cálculo do quociente eleitoral, que decorre da divisão do número total de votos válidos ${ }^{450}$ pelo número de vagas a ser preenchidas na casa legislativa (magnitude da circunscriçãa ${ }^{451}$ ). Deve-se desprezar, no resultado obtido, a fração inferior a 0,5, e considerar equivalente a um a fração superior a 0,5 . O cálculo do quociente eleitoral $(\mathrm{QE})$ pode ser representado pela seguinte formula:

$$
\mathrm{QE}=\frac{\text { votos válidos }}{\mathrm{n}^{\mathrm{o}} \text { de cadeiras em disputa }}
$$

A quantidade de vagas obtidas por cada Partido ou Coligação varia conforme o número de vezes que ultrapassa o quociente eleitoral. Esse "número de vezes" é obtido por meio do cálculo do Quociente Partidário, que decorre da divisão da quantidade de votos válidos obtidos pelo Partido ou Coligação pelo valor do quociente eleitoral, desprezada qualquer fração. $\mathrm{O}$ cálculo do quociente partidário $(\mathrm{QP})$ pode ser representado pela seguinte equação:

447.Art. 106. Determina-se o quociente eleitoral dividindo-se o número de votos válidos apurados pelo de lugares a preencher em cada circunscrição eleitoral, desprezada a fração se igual ou inferior a meio, equivalente a um, se superior.

448.Art. 107 - Determina-se para cada Partido ou coligação o quociente partidário, dividindo-se pelo quociente eleitoral o número de votos válidos dados sob a mesma legenda ou coligação de legendas, desprezada a fração.

449. Art. 109 - Os lugares não preenchidos com a aplicação dos quocientes partidários serão distribuídos mediante observância das seguintes regras: I - dividir-se-á o número de votos válidos atribuídos a cada Partido ou coligação de Partidos pelo número de lugares por ele obtido, mais um, cabendo ao Partido ou coligação que apresentar a maior média um dos lugares a preencher; II - repetir-se-á a operação para a distribuição de cada um dos lugares.

450.Não são computados como válidos os votos nulos ou em branco. É o que dispõe o art. $5^{\circ}$ da Lei 9504/97, segundo o qual “Nas eleições proporcionais, contam-se como válidos apenas os votos dados a candidatos regularmente inscritos e às legendas partidárias."

451. A magnitude da circunscrição é delimitada pela Constituição da República. Deste modo, deve ser observada a quantidade de vagas disponíveis nas casas legislativas - Câmara dos Deputados, Assembleia Legislativa e Câmara dos Vereadores - de acordo com os preceitos contidos, , respectivamente, nos arts. 45 , $\$ 1^{\circ}, 27,29, \mathrm{IV}, 32, \S 3^{\circ}$ (Distrito Federal). 
$\mathrm{QP}=\frac{\text { votos válidos (Partido ou Coligação) }}{\text { Quociente Eleitoral }}$

O Partido ou a Coligação que não obtiver votos em quantidade superior ao quociente eleitoral não terá representação na Casa Legislativa, nos termos do disposto no art. $109, \$ 2^{\circ}$ do Código Eleitora ${ }^{452}$. O quociente partidário representa, portanto, cláusula de barreira, a limitar o acesso à Casa Legislativa aos partidos ou Coligações que atingirem um mínimo de representatividade $e^{453}$.

Se nenhum partido ou coligação atingir o quociente eleitoral, adota-se a sistemática do princípio majoritário, conforme disposição expressa do art. 111, do Código Eleitoral. Neste caso, serão considerados eleitos os candidatos mais votados.

Considerando o fato de que as frações decorrentes do cálculo do Quociente Partidário devem ser desprezadas, há eventualmente sobra de vagas não distribuídas entre os Partidos ou Coligações, e no modelo até então vigente essa seria a única razão para a realização de um novo cálculo para distribuição das vagas remanescentes (sobras). Neste caso, adotando-se a sistemática de maiores médias definidas no Código Eleitoral em seu art. 109, dever-se-ia dividir o número de votos atribuídos a cada Partido ou Coligação pelo número de lugares por eles obtidos (através do quociente partidário), mais um ${ }^{454}$. $\mathrm{O}$ cálculo dos restos eleitorais $(\mathrm{R})$ podia ser assim representado:

$$
\mathrm{R}=\frac{\mathrm{n}^{\mathrm{o}} \text {. de votos obtidos (Partido ou Coligação) }}{\mathrm{n}^{\mathrm{o}} \text {. de vagas obtidas }+1}
$$

Desse modo, o Partido ou Coligação que atingisse a maior média lograria mais uma vaga na casa legislativa. Esse cálculo deveria se repetir até que se esgotassem as sobras, sempre acrescendo ao quociente da equação a nova vaga obtida, quando for o caso ${ }^{455}$.

Após a definição do quociente partidário e distribuição de eventuais sobras, ou seja, uma vez estabelecida a quantidade de vagas a serem preenchidas pelo partido ou coligação, passava-se a definir quais seriam os candidatos empossados. Essa definição ocorria em função da quantidade de votos nominais obtidos, de forma que eram empossados os candidatos mais votados, segundo a votação nominal, independentemente do percentual que essa votação nominal representasse $e^{456}$.

452. Apesar das propostas de modificação deste dispositivo constantes nas Emendas Plenárias 79 e 80, referidas no tópico sobre a reforma, o artigo mantém a mesma previsão. Não foi, portanto, aprovada a alteração que pretendia permitir, a todos os partidos que disputassem as eleições proporcionais, participar da distribuição das vagas remanescentes.

453. Há que se destacar, portanto, que a quantidade de votos obtida individualmente por um candidato não era, até a minirreforma de 2015, determinante para sua eleição no sistema proporcional. Era - e nesse sentido ainda é - necessário que o Partido, ou a Coligação de que faça parte o candidato ultrapasse o quociente eleitoral.

454. Esse "um" somado ao número de vagas já obtidas pelo partido ou coligação representa a vaga (restos) que ele pretende obter. $\mathrm{O}$ sistema adotado para calcula das sobras é o das maiores médias, portanto, aquele partido ou coligação, a que, somada a vaga pretendida às já obtidas permanecer com maior média, recebe a vaga.

455. Esse ponto especificamente, alterado pela Lei 13165/2015, é objeto de discussão na ADI 5420, proposta pelo PGR. Esse tema será abordado em maior profundidade em tópico específico.

456. Importa pontuar que não eram - nem passam a ser, após a minirreforma - realizados novos cálculos para assegurar a representatividade dos partidos que compõem a Coligação eventualmente formulada (cálculo intracoligacional). Esse tema não será objeto de aprofundamento no presente estudo, e a esse respeito 


\section{Distribuição das cadeiras após a Minirreforma de 2015}

As definições do quociente eleitoral e do quociente partidário permanecem inalteradas após a Lei 13165/2015. É dizer, primeiramente define-se o mínimo de votos que o partido ou a coligação precisa receber para obter uma vaga no legislativo dividindo-se o total de votos válidos obtidos pelo total de cadeiras em disputa (o que representa o cálculo do quociente eleitoral), para, na sequencia, verificar quantas vezes o partido ou coligação superaram esse número mínimo de votos, dividindo-se a quantidade de votos válidos obtidos pelo partido/coligação pelo quociente eleitoral (assim alcançando o quociente partidário). Após esse cálculo, deveria ser realizada eventual distribuição de sobras, sendo que nesse momento, já se saberia quantas cadeiras o partido ou a coligação ocupariam na legislatura. Essas cadeiras seriam ocupadas, portanto, pelos candidatos com o maior número de votação pessoal.

O que a Lei 13.165/2015 estabeleceu, primeiramente, foi a exigência de um mínimo de votação nominal para os candidatos a fim de determinar se poderão ou não ocupar as cadeiras obtidas pelo partido ou coligação após a definição do quociente partidário. Esse percentual mínimo deve ser considerado antes mesmo da distribuição das sobras.

Desse modo, com a nova lei o passo-a-passo da contabilização dos votos nas eleições no sistema proporcional passa a seguir o seguinte sistema: (a) cálculo de quociente eleitoral; (b) cálculo de quociente partidário; (c) verificação, no âmbito do partido/coligação se os candidatos mais votados ${ }^{457}$ obtiveram um percentual mínimo de votos; (d) distribuição das sobras; (e) definição dos candidatos que irão ocupar as vagas.

Assim, após a definição inicial de quantas cadeiras o partido ou coligação obtiveram com o cálculo do quociente partidário será necessário verificar se há, no partido ou coligação, tantos candidatos quantos são as cadeiras obtidas que tenham, no mínimo, votação nominal igual ou superior a $10 \%$ do quociente eleitora ${ }^{158}$. Se, portanto, o partido ou a coligação obtiveram na distribuição de quociente partidário dez vagas, mas apenas cinco candidatos possuem, individualmente, votação referente a $10 \%$ do quociente eleitoral, as outras cinco vagas obtidas serão redistribuídas, juntamente com as sobras ${ }^{459}$.

A distribuição das vagas remanescentes também foi alterada pela Lei 13165/2015. Permanece a adoção da sistemática de maiores médias definidas no Código Eleitoral em seu art. 109. Todavia, há no primeiro inciso deste artigo, expressa referência à obrigatória observância do percentual mínimo de votos nominais para os candidatos do partido/coligação:

indica-se a leitura do artigo "Democracia, direitos políticos e sistema proporcional brasileiro: reflexões sobre a adoção de cálculo intracoligacional” (2014), em que o tema é desenvolvido.

457. Neste momento considera-se a quantidade de candidatos referente às cadeiras obtidas pelo partido/ coligação pelo cálculo do quociente partidário.

458. Art. 108, Código Eleitoral: Estarão eleitos, entre os candidatos registrados por um partido ou coligação que tenham obtido votos em número igual ou superior a $10 \%$ (dez por cento) do quociente eleitoral, tantos quantos o respectivo quociente partidário indicar, na ordem da votação nominal que cada um tenha recebido.

459. Art. 108, Parágrafo único, Código Eleitoral: Os lugares não preenchidos em razão da exigência de votação nominal mínima a que se refere o caput serão distribuídos de acordo com as regras do art. 109. 
Art. 109. (...)

I - dividir-se-á o número de votos válidos atribuídos a cada partido ou coligação pelo número de lugares definido para o partido pelo cálculo do quociente partidário do art. 107, mais um, cabendo ao partido ou coligação que apresentar a maior média um dos lugares a preencher, desde que tenha candidato que atenda à exigência de votação nominal mínima; (Redação dada pela Lei no 13.165 , de 2015)

Somente quando não houver "mais partidos ou coligações com candidatos que atendam às duas exigências do inciso I, as cadeiras serão distribuídas aos partidos que apresentem as maiores médias", nos termos do art. 109, III, CE.

Desse modo, deve-se dividir o número de votos atribuídos a cada Partido ou Coligação pelo número de lugares por eles obtidos (através do quociente partidário), mais um ${ }^{460}$. O Partido ou Coligação que atingisse a maior média lograria mais uma vaga na casa legislativa. Esse cálculo deve se repetir até que se esgotassem as sobras.

No texto anterior, destacava-se a necessidade de acrescentar ao quociente da equação a nova vaga obtida, no caso de haver modificação decorrente da distribuição das vagas remanescentes, em virtude da referência ao número de vagas obtido pelo partido ${ }^{461}$. Após a reforma, essa previsão mudou para referir-se ao "número de lugares definido para o partido pelo cálculo do quociente partidário do art. 107", o que se nos apresenta como um divisor fixo. É dizer, a cada repetição do cálculo para repartição das vagas remanescentes, o resultado seria o mesmo para cada partido/coligação. Este, precisamente, o ponto questionado na ADI 5420 proposta pelo Procurador Geral da República, a ser desenvolvido nos tópicos seguintes.

Interessa destacar, no presente estudo, algumas questões referentes ao sistema proporcional brasileiro e os arranjos institucionais que lhe são peculiares, para, nos tópicos seguintes, considerar o impacto das alteraçóes promovidas na qualidade de nossa democracia.

No modelo de sistema proporcional adotado no Brasil para a maioria dos cargos do Poder Legislativo o eleitor escolhe seu candidato entre aqueles apresentados em lista não ordenada por um Partido Político ou uma Coligação. Os eleitores no Brasil podem optar por votar nominalmente em seu candidato, ou somente na legenda partidária. A Coligação formada não possui legenda própria, de modo que o eleitor poderá votar na legenda de determinado partido coligado e ser responsável pela eleição de candidato de outro partido coligado, mesmo que com ele não possua nenhuma afinidade - isso porque a autonomia para formação de coligações não exige, a rigor, que sejam consideradas questões afetas à ideologia dos partidos coligados ${ }^{462}$.

Com a alteração legislativa essa distorção do voto passa a ser ainda maior. Isso porque além da possibilidade de o voto - tanto nominal quanto em legenda para um partido coli-

460. Esse "um" somado ao número de vagas já obtidas pelo partido ou coligação representa a vaga (restos) que ele pretende obter. O sistema adotado para calcula das sobras é o das maiores médias, portanto, aquele partido ou coligação, a que, somada a vaga pretendida às já obtidas permanecer com maior média, recebe a vaga.

461. Art. 109, I, CE (texto anterior)- dividir-se-á o número de votos válidos atribuídos a cada Partido ou coligação de Partidos pelo número de lugares por ele obtido, mais um, cabendo ao Partido ou coligação que apresentar a maior média um dos lugares a preencher.

462. A efemeridade das Coligações Partidárias, bem como o modo como que são formadas e as relações entre os partidos antes e após as eleições não serão objeto de aprofundamento no presente estudo. Sobre o tema, remete-se o leitor ao artigo intitulado "Partidos políticos, coligações e blocos de atuação nas casas legislativas: O Congresso Nacional Brasileiro” (2015). 
gado - poder beneficiar outro partido coligado, há também a possibilidade de ser remetido a outros partidos não coligados. $\mathrm{Na}$ verdade, isso decorre da exigência de votação nominal mínima, para fins de definição das vagas obtidas pelo partido/coligação.

Quando o partido obtiver, no total - considerando-se os votos de legenda e os votos nominais - mais cadeiras do que candidatos com o percentual mínimo de votos exigido (igual ou superior a $10 \%$ do quociente eleitoral) ele perderá essas vagas, que serão redistribuídas, juntamente com as vagas remanescentes. Com o novo sistema, temos, portanto, no cálculo tratado pelo art. 109 do Código Eleitoral, duas espécies de cadeiras na distribuição (ou redistribuição): (a) aquelas, remanescentes, em decorrência do fato de as contas de quociente eleitoral e partidário não serem, necessariamente, exatas; e (b), as que não puderam ser aproveitadas pelo partido ou coligação em virtude de não haver, no mesmo, candidatos suficientes com o percentual mínimo de votos nominais exigidos pela novel lei.

\section{Ação Direta de Inconstitucionalidade ADI5420}

A ADI 5420 foi proposta pelo Procurador Geral da República e distribuída, em 26/11/2015 ao Min. Dias Toffoli, Relator, e tem como objeto impugnar exatamente a alteração promovida pela Lei 13165/2015 no art. 109 do Código Eleitoral sobre a fórmula para realização da distribuição das vagas remanescentes (sobras e vagas não preenchidas em virtude do mínimo de votação nominal) e a exigência da votação nominal mínima para realização dessa distribuição. É o que se extrai da Petição Inicial da ADI:

Pelo critério da Lei 13.165/2015, o partido ou coligação que obtiver a maior média na primeira operação de atribuição das vagas remanescentes logrará todas as demais. Isso implica severa distorção das regras do sistema de representação proporcional, pois, ao final da distribuição das sobras, a composição das casas legislativas não guardará respeito à votação conquistada pelas forças políticas.

Segundo o PGR, o art. 4º da Lei 13165/2015, no trecho em que modifica o art. 109 do Código Eleitoral seria inconstitucional por violar o sistema de representação proporcional previsto no art. 45 da Constituição da República. Cumpre destacar que no corpo da Petição Inicial, questiona-se, para além do cálculo da distribuição das vagas remanescentes, a instituição de um mínimo de votação nominal prevista no art. 108 do Código Eleitoral após as modificações promovidas pela Lei 13165/2015.

No entanto, ao delimitar o objeto da petição, o autor apenas questionou o novo texto do art. 109 do Código Eleitoral, não fazendo o mesmo com relação ao art. 108. O art. 109, I, $\mathrm{CE}, \mathrm{faz}$ referência à exigência da votação nominal dos candidatos, mas como decorrência da previsão contida no art. 108. É, portanto, de estranhar, o fato de não haver impugnação direta ao referido dispositivo ${ }^{463}$ (art. 108, CE, aletrado pela Lei 13165/2015).

463. É possível imaginar que tal postura decorra de uma análise de cunho objetivo, realizada no presente estudo nos tópicos seguintes, e constante na petição inicial da ADI 5420, sobre os prováveis impactos dessa modificação legislativa. 
Desse modo, entre os pedidos e requerimentos formulados, o PGR pleiteou pela concessão de medida cautelar para a suspensão da eficácia das normas impugnadas - especificamente art. 4 da Lei 13165/2015, no trecho em que dá nova redação ao art. 109, I a III do Código Eleitoral. Essa medida cautelar foi parcialmente concedida, por decisão monocrática do Min. Relator, datada de 03/12/2015, para suspender a eficácia da expressão "número de lugares definido para o partido pelo cálculo do quociente partidário do art. 107”, constante no art. 109, I do Código Eleitoral, alterado pela Lei 13165/2015. Determinou-se a manutenção do critério de cálculo da distribuição das vagas remanescentes anterior à edição da Lei 131365/2015.

Em sua decisão, o Min. Dias Toffoli compreende que a alteração da norma, no que diz respeito à adoção de um divisor fixo na distribuição das vagas remanescentes "desnatura o sistema proporcional no cálculo das sobras eleitorais", eis que evidenciaria a "a desconsideração da distribuição eleitoral de cadeiras baseada na proporcionalidade (art. 45 da CF/88), que é intrínseca ao sistema proporcional".

$\mathrm{Na}$ que tange à parte final do art. 109, I, CE, sobre a inserção da exigência de votação nominal mínima referente a $10 \%$ do quociente eleitoral para distribuição das vagas remanescentes, o Min. Relator não identifica inconstitucionalidade ou distorção do sistema proporcional,

uma vez que não excluiu do processo de distribuição das vagas a essencialidade da quantidade de votos total obtida pelo partido ou coligação, uma vez que esse dado apurado pelo quociente partidário - continua sendo considerado na distribuição de vagas aos partidos.

O Min. Relator destaca, inclusive, em sua decisão, entendimento segundo o qual a exigência de votação nominal mínima estabelecida pela novel lei não viola o sistema proporcional brasileiro, senão que reforça uma característica que lhe é peculiar: "o voto do eleitor brasileiro, mesmo nas eleições proporcionais, em geral, se dá em favor de determinado candidato".

Trata-se, contudo, de decisão monocrática que analisou medida cautelar pleiteada na inicial. A ADI deve ser devidamente instruída para que possa ser devidamente analisada pelo Supremo Tribunal Federal. Por hora, pode-se esperar que nas eleições de 2016 o cálculo da distribuição das sobras seja realizado, no que diz respeito ao seu divisor, com base na legislação antiga, ou seja, considerando-se a quantidade de vagas obtidas pelo partido ou coligação.

\section{Possíveis efeitos práticos da alteração legislativa - análise de dados}

Para fins de comparação, tomamos como exemplo os resultados obtidos no Município de Belo Horizonte, capital de Minas Gerais, nas Eleições Municipais de 2012, para o cargo de Vereador. Segundo a sistemática de distribuição de cadeiras aplicável à época, os resultados podem ser apresentados conforme o Quadro 1- Resultado das Eleições Municipais 2012. 
Quadro 1: Resultado das Eleiçóes Municipais Belo Horizonte/MG 2012

Vereador - Cadeiras/partido no município - Resultado

\begin{tabular}{|c|c|c|c|c|c|c|}
\hline Part./Colig. & Votos & $\%\left(^{*}\right)$ & $\begin{array}{l}\text { Quoc. } \\
\text { Eleitoral }\end{array}$ & $\begin{array}{l}\text { Quoc. } \\
\text { Partidário }\end{array}$ & $\begin{array}{l}\text { Cadeiras - } \\
\text { Quoc.Part. }\end{array}$ & $\begin{array}{l}\text { Vagas } \\
\text { pela média }\end{array}$ \\
\hline PC do B & 54939 & 4,37 & 30650 & 1,79 & 1 & 1 \\
\hline $\mathrm{PCO}$ & 399 & 0,03 & 30650 & 0,01 & 0 & 0 \\
\hline PDT & 40316 & 3,21 & 30650 & 1,32 & 1 & 0 \\
\hline PHS & 45808 & 3,65 & 30650 & 1,49 & 1 & 0 \\
\hline $\mathrm{PMN}$ & 23335 & 1,86 & 30650 & 0,76 & 0 & 0 \\
\hline PPL & 3221 & 0,26 & 30650 & 0,11 & 0 & 0 \\
\hline $\mathrm{PP} / \mathrm{PT}$ do B & 103287 & 8,22 & 30650 & 3,37 & 3 & 1 \\
\hline PPS/PSD & 71465 & 5,69 & 30650 & 2,33 & 2 & 0 \\
\hline PRB & 54498 & 4,34 & 30650 & 1,78 & 1 & 1 \\
\hline PRP & 33397 & 2,66 & 30650 & 1,09 & 1 & 0 \\
\hline $\mathrm{PR} / \mathrm{PSDB}$ & 82460 & 6,56 & 30650 & 2,69 & 2 & 1 \\
\hline PRTB & 17300 & 1,38 & 30650 & 0,56 & 0 & 0 \\
\hline PSB & 167072 & 13,3 & 30650 & 5,45 & 5 & 1 \\
\hline PSDC & 56301 & 4,48 & 30650 & 1,84 & 1 & 1 \\
\hline PSL/DEM & 54943 & 4,37 & 30650 & 1,79 & 1 & 1 \\
\hline PSOL/PCB & 11135 & 0,89 & 30650 & 0,36 & 0 & 0 \\
\hline PSTU & 4131 & 0,33 & 30650 & 0,13 & 0 & 0 \\
\hline PTB/PSC & 53571 & 4,26 & 30650 & 1,75 & 1 & 1 \\
\hline PTC & 51596 & 4,11 & 30650 & 1,68 & 1 & 0 \\
\hline PTN & 90286 & 7,18 & 30650 & 2,95 & 2 & 1 \\
\hline $\mathrm{PT} / \mathrm{PMDB}$ & 182398 & 14,51 & 30650 & 5,95 & 5 & 2 \\
\hline PV & 54792 & 4,36 & 30650 & 1,79 & 1 & 1 \\
\hline
\end{tabular}

(*) Percentual sobre os votos válidos para o cargo no município

Candidatos com registro indeferido e pendente no TSE não são apresentados.

Seus votos foram considerados nulos no momento dessa consulta.

Atualizado em 11/01/2016 às 16:29 Fonte: TRE/MG (2012)

Das 41 cadeiras em disputa, 29 foram distribuídas regularmente por meio do quociente partidário, e 12 por meio de distribuição de sobras, conforme a fórmula de maiores médias. Para testar esse resultado segundo o novo modelo, serão utilizados os dados disponíveis nas Estatísticas do Tribunal Superior Eleitoral e nos Resultados disponibilizados pelo Tribunal Regional Eleitoral de Minas Gerais nos respectivos sítios eletrônicos, referentes às eleições de 2012. 
O Quadro 2 traz os dados gerais sobre a votação no Município para o cargo de Vereador. Com isso, temos o total de votos válidos - 1.256.650 - e o número de cadeiras em disputa - 41. Esses dados permitem realizar o cálculo do quociente eleitoral (QE), de acordo com a fórmula a seguir, que permanece sem modificação:

$$
\mathrm{QE}=\frac{1256650 \text { (total de votos válidos) }}{41(\text { cadeiras em disputa }} \quad \mathrm{QE}=30650
$$

Quadro 2: Eleições Municipais de 2012 - Vereador - Belo Horizonte/MG

\begin{tabular}{l|l|l|l|l|l|l|}
\hline Abrangência & $\begin{array}{l}\text { Qt } \\
\text { Compareci- } \\
\text { mento }\end{array}$ & $\begin{array}{l}\text { Qt Votos } \\
\text { Nominais }\end{array}$ & $\begin{array}{l}\text { Qt Votos } \\
\text { Legenda }\end{array}$ & $\begin{array}{l}\text { Qt Votos } \\
\text { em Branco }\end{array}$ & $\begin{array}{l}\text { Qt Votos } \\
\text { Nulos }\end{array}$ & $\begin{array}{l}\text { Qt Votos } \\
\text { Válidos }\end{array}$ \\
\hline $\begin{array}{l}\text { BELO } \\
\text { H O R I } \\
\text { ZONTE }\end{array}$ & 1.508 .930 & 1.120 .874 & 135.776 & 139.383 & 112.897 & 1.256 .650 \\
\hline Total Geral & 1.508 .930 & 1.120 .874 & 135.776 & 139.383 & 112.897 & 1.256 .650 \\
\hline
\end{tabular}

Fonte: Estatísticas e Resultado das Eleições TSE (2012)

Desse modo temos que os partidos ou coligações precisavam obter, nas eleições de 2012, pelo menos 30.650 votos para eleger ao menos um representante. Para verificar quantos representantes cada partido elege, passa-se ao cálculo do quociente partidário, ou seja, divide-se o total de votos válidos obtidos pelo partido (votos nominais ou de legenda) pelo quociente partidário. A título de exemplo, consta do Quadro 1 que o PC do B obteve, naquele ano, 54939 votos. Desse modo, o cálculo do quociente partidário (QP) restaria assim representado, para este partido que concorreu isoladamente no pleito de 2012:

$$
\mathrm{QP}(\mathrm{PC} \text { do } \mathrm{B})=\frac{54939(\text { total de votos válidos do } \mathrm{PC} \mathrm{do} \mathrm{B})}{30650(\text { Quociente eleitoral })} \quad \mathrm{QP}(\mathrm{PC} \text { do } \mathrm{B})=1,79
$$

O PC do B obteve, a partir do quociente partidário, uma cadeira. Importa lembrar que qualquer casa decimal nesse cálculo deve ser desconsiderada, ou seja, o resultado será sempre arredondado para o menor número inteiro. De acordo com o método antigo, passaríamos para a distribuição das sobras, e conforme se verifica no Quadro 1, o PC do B seria beneficiado com mais uma cadeira.

A partir da modificação promovida pela Lei 13165/2015, após o cálculo do quociente partidário será necessário verificar se o partido em questão - no nosso exemplo o PC do B - possui candidatos que tenham atingido o mínimo necessário na votação nominal, ou seja, pelo menos $10 \%$ do quociente eleitoral. Em 2012, esse quociente foi de 30.650, de modo que o candidato deveria ter recebido, no mínimo, 3.065 votos nominais. O Quadro 3 nos fornece a votação nominal dos eleitos, para que possamos realizar essa comparação. 
Quadro 3: Eleições Municipais - Votação Nominal dos Eleitos em Belo Horizonte/MG

Por município - Resultado Nominal

\begin{tabular}{|c|c|c|c|c|}
\hline Candidato - nome completo & Part./Colig. & Votos & $\%\left({ }^{*}\right)$ & Situação \\
\hline $\begin{array}{l}\text { FERNANDO LUIZ COSTA MAR- } \\
\text { CIANO }\end{array}$ & PSB & 11950 & 0,95 & Eleito por QP \\
\hline ARNALDO AUGUSTO DE GODOY & $\begin{array}{l}\mathrm{PT}(\mathrm{PT} / \\
\mathrm{PMDB})\end{array}$ & 11538 & 0,92 & Eleito por QP \\
\hline EDSON MOREIRA DA SILVA & PTN & 10532 & 0,84 & Eleito por QP \\
\hline RUBENS GONÇALVES DE BRITO & PTN & 10102 & 0,8 & Eleito por QP \\
\hline $\begin{array}{l}\text { MARCELO GUILHERME DE ARO } \\
\text { FERREIRA }\end{array}$ & PHS & 9412 & 0,75 & Eleito por QP \\
\hline $\begin{array}{l}\text { PEDRO LUIZ NEVES VICTER } \\
\text { ANANIAS }\end{array}$ & $\begin{array}{l}\mathrm{PT}(\mathrm{PT} / \\
\mathrm{PMDB})\end{array}$ & 9284 & 0,74 & Eleito por QP \\
\hline BRUNO MARTUCHELE DE SALES & PDT & 9262 & 0,74 & Eleito por QP \\
\hline DANIEL DINIZ NEPOMUCENO & PSB & 9175 & 0,73 & Eleito por QP \\
\hline $\begin{array}{l}\text { MARCELO HENRIQUE TEIXEIRA } \\
\text { DIAS }\end{array}$ & PRP & 8846 & 0,7 & Eleito por QP \\
\hline IRAN ALMEIDA BARBOSA & $\begin{array}{l}\text { PMDB } \\
\text { (PT/ } \\
\text { PMDB) }\end{array}$ & 8605 & 0,68 & Eleito por QP \\
\hline $\begin{array}{l}\text { WELLINGTON GONÇALVES DE } \\
\text { MAGALHÃES }\end{array}$ & PTN & 8436 & 0,67 & $\begin{array}{l}\text { Eleito por mé- } \\
\text { dia }\end{array}$ \\
\hline NILTON CESAR RODRIGUES & PSB & 8386 & 0,67 & Eleito por QP \\
\hline $\begin{array}{l}\text { WENDEL CRISTIANO SOARES } \\
\text { DE MESQUITA }\end{array}$ & PSB & 8280 & 0,66 & Eleito por QP \\
\hline AUTAIR GOMES PEREIRA & $\begin{array}{l}\text { PSC (PTB/ } \\
\text { PSC) }\end{array}$ & 8052 & 0,64 & Eleito por QP \\
\hline ANTONIO TORRES GONÇALVES & $\begin{array}{l}\text { PSL (PSL/ } \\
\text { DEM) }\end{array}$ & 7960 & 0,63 & Eleito por QP \\
\hline JULIANO LOPES LOBATO & PSDC & 7907 & 0,63 & Eleito por QP \\
\hline EDVALDO PICCININI TEIXEIRA & PSB & 7480 & 0,6 & Eleito por QP \\
\hline $\begin{array}{l}\text { LEONARDO SILVEIRA DE CASTRO } \\
\text { PIRES }\end{array}$ & $\begin{array}{l}\mathrm{PSDB}(\mathrm{PR} / \\
\mathrm{PSDB})\end{array}$ & 7441 & 0,59 & Eleito por QP \\
\hline JOSE TARCISIO CAIXETA & $\begin{array}{l}\mathrm{PT}(\mathrm{PT} / \\
\mathrm{PMDB})\end{array}$ & 7364 & 0,59 & Eleito por QP \\
\hline ALEXANDRE JOSE GOMES & PSB & 7241 & 0,58 & Eleito por média \\
\hline RONALDO WAGNER GONTIJO & $\begin{array}{l}\text { PPS (PPS/ } \\
\text { PSD) }\end{array}$ & 7237 & 0,58 & Eleito por QP \\
\hline GILSON LUIZ REIS & $\mathrm{PC}$ do B & 7010 & 0,56 & Eleito por QP \\
\hline JORGE LUIZ DOS SANTOS & $\mathrm{PRB}$ & 7008 & 0,56 & Eleito por QP \\
\hline
\end{tabular}




\begin{tabular}{|c|c|c|c|c|}
\hline ADRIANO DE SOUZA VENTURA & $\begin{array}{l}\mathrm{PT}(\mathrm{PT} / \\
\mathrm{PMDB})\end{array}$ & 6931 & 0,55 & Eleito por QP \\
\hline $\begin{array}{l}\text { SÉRGIO FERNANDO PEREIRA } \\
\text { DE PINHO TAVARES }\end{array}$ & PV & 6916 & 0,55 & Eleito por QP \\
\hline NILTON DE FREITAS PAIM & $\begin{array}{l}\mathrm{PT}(\mathrm{PT} / \\
\mathrm{PMDB})\end{array}$ & 6904 & 0,55 & Eleito por média \\
\hline ORLEI PEREIRA DA SILVA & \begin{tabular}{|l}
$\mathrm{PT}$ do B \\
(PP/PT do \\
$\mathrm{B})$ \\
\end{tabular} & 6791 & 0,54 & Eleito por QP \\
\hline SILVIO HIGINO DE REZENDE & $\begin{array}{l}\mathrm{PT}(\mathrm{PT} / \\
\mathrm{PMDB}) \\
\end{array}$ & 6628 & 0,53 & Eleito por média \\
\hline PABLO CÉSAR DE SOUZA & $\begin{array}{l}\text { PSDB (PR/ } \\
\text { PSDB) }\end{array}$ & 6608 & 0,53 & Eleito por QP \\
\hline WAGNER MESSIAS SILVA & $\begin{array}{l}\mathrm{DEM}(\mathrm{PSL} / \\
\mathrm{DEM})\end{array}$ & 6605 & 0,53 & Eleito por média \\
\hline JOEL GOMES MOREIRA FILHO & PTC & 6496 & 0,52 & Eleito por QP \\
\hline WAGNER MARIANO JUNIOR & $\mathrm{PRB}$ & 6461 & 0,51 & Eleito por média \\
\hline $\begin{array}{l}\text { ELAINE MATOZINHOS RIBEIRO } \\
\text { GONÇALVES }\end{array}$ & $\begin{array}{l}\mathrm{PTB}(\mathrm{PTB} / \\
\mathrm{PSC})\end{array}$ & 6175 & 0,49 & Eleito por média \\
\hline LEONARDO JOSÉ DE MATTOS & PV & 6105 & 0,49 & Eleito por média \\
\hline SANDRO SALTARA & PC do B & 5748 & 0,46 & Eleito por média \\
\hline VALDIVINO PEREIRA DE AQUINO & $\begin{array}{l}\text { PPS (PPS/ } \\
\text { PSD) }\end{array}$ & 5710 & 0,45 & Eleito por QP \\
\hline HENRIQUE HIGIDIO BRAGA & $\begin{array}{l}\mathrm{PSDB}(\mathrm{PR} / \\
\mathrm{PSDB})\end{array}$ & 5279 & 0,42 & Eleito por média \\
\hline VILMO FERREIRA GOMES & \begin{tabular}{|l}
$\mathrm{PT}$ do B \\
(PP/PT do \\
$\mathrm{B})$ \\
\end{tabular} & 5098 & 0,41 & Eleito por QP \\
\hline VERENILDO DOS SANTOS & \begin{tabular}{|l} 
PT do B \\
(PP/PT do \\
B) \\
\end{tabular} & 4945 & 0,39 & Eleito por QP \\
\hline JOSE FRANCISCO FILHO & $\begin{array}{ll}\mathrm{PT} \text { do } \\
\text { (PP/PT do } \\
\mathrm{B} \text { ) } \\
\end{array}$ & 4546 & 0,36 & Eleito por média \\
\hline ELVES RODRIGUES CÔRTES & PSDC & 3537 & 0,28 & Eleito por média \\
\hline
\end{tabular}

$\left.{ }^{*}\right)$ Percentual sobre os votos válidos para o cargo no município

As quantidades de votos dos candidatos com registros pendentes no TSE não são apresentadas nesta consulta.

Atualizado em 11/01/2016 às 17:46 
O candidato Gilson Luiz Reis, eleito por Quociente Partidário pelo PC do B obteve 7.010 votos, superando, portanto, o mínimo exigido pela nova lei. Em vista do Quadro 3 é possível constatar que o resultado das eleições de 2012 não seria alterado, se acaso fosse adota a nova sistemática de exigir o mínimo de votação pessoal, pois todos os candidatos eleitos seja por quociente partidário ou por média - obtiveram votação nominal superior à $10 \%$ do quociente eleitoral.

$\mathrm{Na}$ verdade, conforme os dados disponibilizados no sítio eletrônico do Tribunal Superior Eleitoral, é possível identificar que a grande maioria dos votos do eleitorado no Município de Belo Horizonte são nominais, e não de legenda.

Quadro 4: Votos nominais e de legenda em relação aos votos válidos - BH/2012

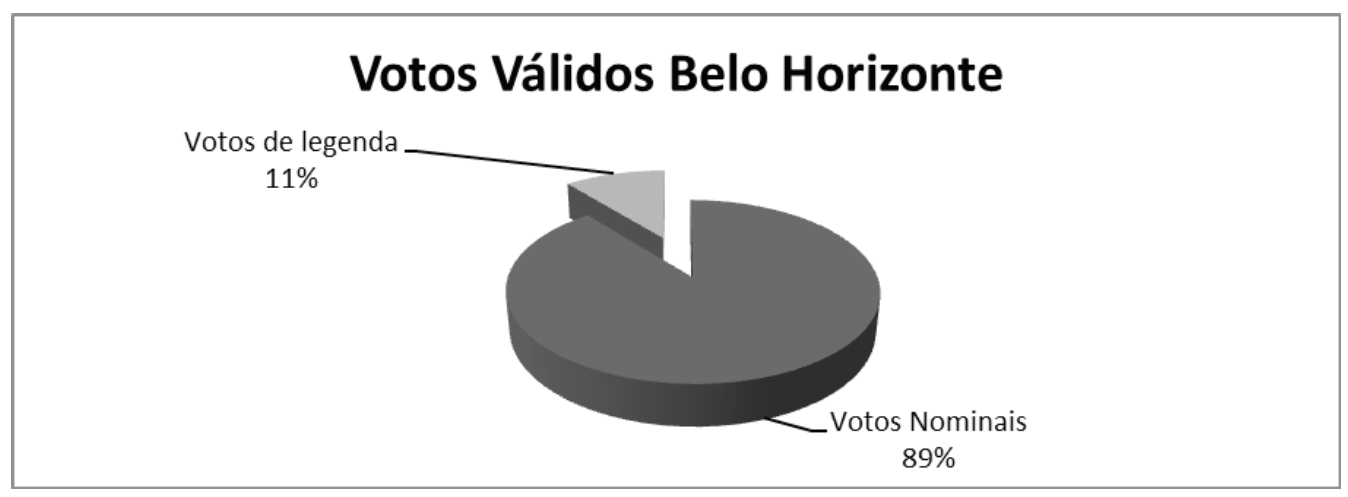

Fonte: Estatísticas e Resultado das Eleições TSE (2012)

De fato, essa característica de maior votação nominal nas eleições municipais de 2012 para o cargo de vereador é nacional, conforme se pode verificar no Quadro 5:

Quadro 5: Votos nominais e de legenda em relação aos votos válidos - Eleições Municipais de 2012

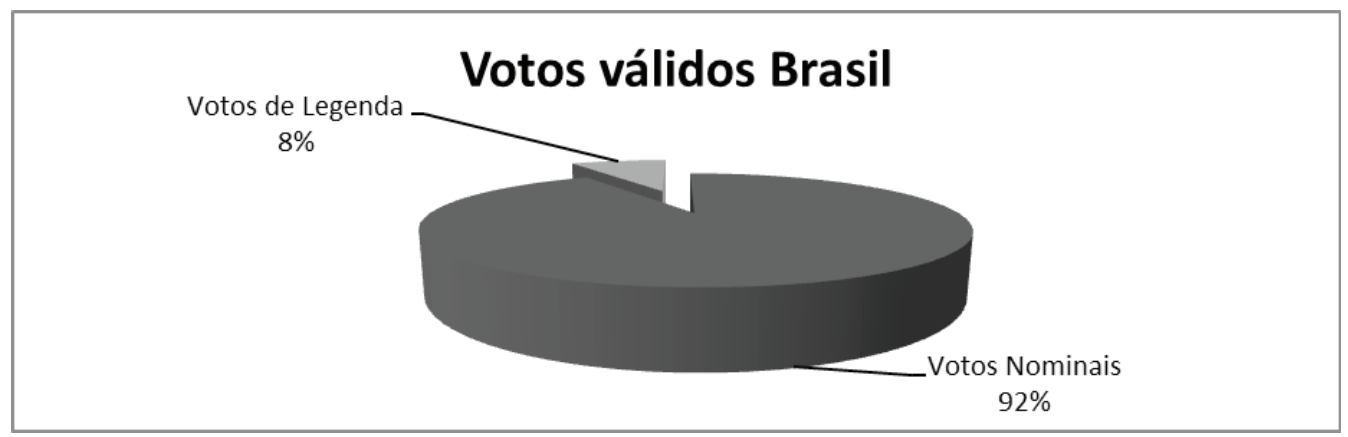

Fonte: Estatísticas e Resultado das Eleições TSE (2012)

Analisando os dados sobre estatísticas e resultados das eleições do TSE, é possível concluir que entre todos os vereadores eleitos em todas as capitais dos Estados brasileiro, apenas dois não teriam atingido o mínimo de votação nominal doravante exigido pela legislação eleitoral. É o que se pode verificar no Quadro 6: 
Quadro 6: Eleições Municipais - Votação Nominal dos Eleitos em todas as Capitais

\begin{tabular}{|c|c|c|c|c|}
\hline Estado & Capital & \begin{tabular}{|l|} 
Quociente \\
Eleitoral
\end{tabular} & $\begin{array}{l}\text { No de } \\
\text { vagas }\end{array}$ & $\begin{array}{l}\text { Análise da votação nominal dos } \\
\text { vereadores eleitos }\end{array}$ \\
\hline Acre & Rio Branco & 10.567 & 17 & Todos os eleitos atingiram $10 \% \mathrm{QE}$ \\
\hline Alagoas & Maceió & 19.680 & 21 & Todos os eleitos atingiram $10 \% \mathrm{QE}$ \\
\hline Amapá & Macapá & 8.873 & 23 & Todos os eleitos atingiram 10\% QE \\
\hline Amazonas & Manaus & 22.977 & 41 & Todos os eleitos atingiram $10 \% \mathrm{QE}$ \\
\hline Bahia & Salvador & 30.003 & 43 & Todos os eleitos atingiram $10 \% \mathrm{QE}$ \\
\hline Ceara & Fortaleza & 29.050 & 43 & Todos os eleitos atingiram $10 \% \mathrm{QE}$ \\
\hline $\begin{array}{l}\text { Espírito } \\
\text { Santo }\end{array}$ & Vitória & 12.142 & 15 & Todos os eleitos atingiram $10 \% \mathrm{QE}$ \\
\hline Goiás & Goiânia & 18.141 & 35 & Todos os eleitos atingiram $10 \% \mathrm{QE}$ \\
\hline Maranhão & São Luiz & 16.597 & 31 & Todos os eleitos atingiram $10 \% \mathrm{QE}$ \\
\hline $\begin{array}{l}\text { Mato } \\
\text { Grosso }\end{array}$ & Cuiabá & 12.301 & 25 & Todos os eleitos atingiram $10 \% \mathrm{QE}$ \\
\hline $\begin{array}{l}\text { Mato Grosso } \\
\text { do Sul }\end{array}$ & Campo Grande & 14.224 & 29 & Todos os eleitos atingiram 10\% QE \\
\hline $\begin{array}{l}\text { Minas } \\
\text { Gerais }\end{array}$ & Belo Horizonte & 30.650 & 41 & Todos os eleitos atingiram $10 \% \mathrm{QE}$ \\
\hline Pará & Belém & 21.528 & 35 & Todos os eleitos atingiram $10 \% \mathrm{QE}$ \\
\hline Paraíba & João Pessoa & 13.781 & 27 & Todos os eleitos atingiram $10 \% \mathrm{QE}$ \\
\hline Paraná & Curitiba & 23.961 & 38 & Todos os eleitos atingiram $10 \% \mathrm{QE}$ \\
\hline Pernambuco & Recife & 22.531 & 39 & Todos os eleitos atingiram $10 \% \mathrm{QE}$ \\
\hline Piauí & Terezina & 14.584 & 29 & Todos os eleitos atingiram $10 \% \mathrm{QE}$ \\
\hline $\begin{array}{l}\text { Rio de } \\
\text { Janeiro }\end{array}$ & Rio de Janeiro & 61.051 & 51 & $\begin{array}{l}\text { Não atingiu o percentual mínimo: } \\
\text { MARCELO HENRIQUES BAP- } \\
\text { TISTA - PHS (6015 votos) }\end{array}$ \\
\hline $\begin{array}{l}\text { Rio Grande } \\
\text { do Norte }\end{array}$ & Natal & 13.170 & 29 & $\begin{array}{l}\text { Não atingiu o percentual mínimo: } \\
\text { MARCOS ANTONIO FERREI- } \\
\text { RA DA SILVA - PSOL ( } 717 \text { votos) }\end{array}$ \\
\hline $\begin{array}{l}\text { Rio Grande } \\
\text { do Sul }\end{array}$ & Porto Alegre & 20.937 & 36 & Todos os eleitos atingiram $10 \% \mathrm{QE}$ \\
\hline Rondônia & Porto Velho & 10.959 & 21 & Todos os eleitos atingiram $10 \% \mathrm{QE}$ \\
\hline Roraima & Boa Vista & 6.988 & 21 & Todos os eleitos atingiram $10 \% \mathrm{QE}$ \\
\hline $\begin{array}{l}\text { Santa } \\
\text { Catarina }\end{array}$ & Florianópolis & 10.284 & 23 & Todos os eleitos atingiram $10 \% \mathrm{QE}$ \\
\hline São Paulo & São Paulo & 103.843 & 55 & Todos os eleitos atingiram $10 \% \mathrm{QE}$ \\
\hline Sergipe & Aracajú & 12.749 & 24 & Todos os eleitos atingiram $10 \% \mathrm{QE}$ \\
\hline Tocantins & Palmas & 6.401 & 19 & Todos os eleitos atingiram $10 \% \mathrm{QE}$ \\
\hline
\end{tabular}


Fonte: Estatísticas Eleições 2012, TSE ${ }^{464}$

Somente os vereadores Marcelo Henriques Batista, do PHS do Rio de Janeiro/RJ e Marcos Antônio Ferreira da Silva, do PSOL de Natal/RN não teriam o mínimo de votos nominais necessários para a sua nomeação. Isso, destaque-se, no primeiro momento, eis que, conforme a nova lei, se após a (re)distribuição das vagas não houver candidato que atenda a exigência do percentual mínimo de votos nominais, as vagas serão destinadas aso partidos com maiores médias, independente de haver candidato que atenda à exigência da votação nominal (art. 109, III, CE).

Mesmo em Municípios menores, essa modificação não trouxe distorções, considerando-se os resultados de 2012. A título de exemplo, o Município Abadia dos Dourados/MG, com eleitorado apurado de 5.660 eleitores e 9 cadeiras em disputa: todos os candidatos eleitos atingiram o mínimo exigido $-10 \%$ do quociente eleitoral ( 54 votos). É o que se pode verificar nos Quadros 7 e 8:

Quadro 7: Resultado das Eleições Municipais Abadia dos Dourados/MG 2012

Vereador - Cadeiras/partido no município - Resultado

\begin{tabular}{|c|c|c|c|c|c|c|}
\hline Part./Colig. & Votos & $\%\left(^{*}\right)$ & $\begin{array}{l}\text { Quoc. } \\
\text { Eleitoral }\end{array}$ & $\begin{array}{l}\text { Quoc. } \\
\text { Partidário }\end{array}$ & $\begin{array}{l}\text { Cadeiras - } \\
\text { Quoc.Part. }\end{array}$ & $\begin{array}{l}\text { Vagas } \\
\text { pela } \\
\text { média }\end{array}$ \\
\hline $\mathrm{PRB} / \mathrm{DEM}$ & 1667 & 33,99 & 545 & 3,06 & 3 & 0 \\
\hline $\begin{array}{l}\mathrm{PTB} / \mathrm{PMDB} / \mathrm{PR} / \\
\mathrm{PSB} / \mathrm{PSDB}\end{array}$ & 2676 & 54,56 & 545 & 4,91 & 4 & 1 \\
\hline $\mathrm{PT} / \mathrm{PSC} / \mathrm{PPS}$ & 562 & 11,46 & 545 & 1,03 & 1 & 0 \\
\hline \multicolumn{7}{|c|}{$\left(^{*}\right)$ Percentual sobre os votos válidos para o cargo no município } \\
\hline \multicolumn{6}{|c|}{ Candidatos com registro indeferido e pendente no TSE não são apresentados. } & \\
\hline \multicolumn{6}{|c|}{ Seus votos foram considerados nulos no momento dessa consulta. } & \\
\hline $11 /$ & 1001 & 10 & & & & \\
\hline
\end{tabular}

464. Para organizar o Quadro 6 foram analisados os dados disponíveis no sítio eletrônico do TSE, e repetida análise demostrada nesse estudo para o Município de Belo Horizonte/MG: conhecido o quociente eleitoral de cada município e, a partir dessa dado, foram conferidos os resultados das eleições de cada município, e verificou-se a votação nominal de todos os vereadores eleitos, se todos os vereadores eleitos, para conferir se ultrapassavam o limite mínimo de votação nominal doravante exigido pela lei. 
Quadro 8: Eleições Municipais - Votação Nominal dos Eleitos em Abadia dos Dourados/MG

Por município - Resultado Nominal

\begin{tabular}{|c|c|c|c|c|}
\hline Candidato - nome completo & Part./Colig. & Votos & $\%\left({ }^{*}\right)$ & Situação \\
\hline $\begin{array}{l}\text { VALERIO ANTONIO } \\
\text { DE OLIVEIRA }\end{array}$ & $\begin{array}{l}\mathrm{PR}(\mathrm{PTB} / \mathrm{PMDB} / \\
\mathrm{PR} / \mathrm{PSB} / \mathrm{PSDB}) \\
\end{array}$ & 320 & 6,52 & Eleito por QP \\
\hline $\begin{array}{l}\text { GILVANE VARGAS DE } \\
\text { MELO }\end{array}$ & $\mathrm{PRB}$ (PRB/DEM) & 269 & 5,48 & Eleito por QP \\
\hline $\begin{array}{l}\text { JOSE RAMOS DA SILVA } \\
\text { SOBRINHO }\end{array}$ & $\mathrm{PRB}(\mathrm{PRB} / \mathrm{DEM})$ & 267 & 5,44 & Eleito por QP \\
\hline $\begin{array}{l}\text { NORICO BERNARDES } \\
\text { PERES }\end{array}$ & $\begin{array}{l}\text { PTB (PTB/PMDB/ } \\
\text { PR/PSB/PSDB) }\end{array}$ & 263 & 5,36 & Eleito por QP \\
\hline RUY PEREIRA DAMAS & $\begin{array}{l}\mathrm{PTB}(\mathrm{PTB} / \mathrm{PMDB} / \\
\mathrm{PR} / \mathrm{PSB} / \mathrm{PSDB})\end{array}$ & 232 & 4,73 & Eleito por QP \\
\hline $\begin{array}{l}\text { SEBASTIÃO DA SILVA } \\
\text { RAMOS }\end{array}$ & $\begin{array}{l}\mathrm{PMDB}(\mathrm{PTB} / \\
\mathrm{PMDB} / \mathrm{PR} / \mathrm{PSB} / \\
\mathrm{PSDB})\end{array}$ & 230 & 4,69 & Eleito por QP \\
\hline $\begin{array}{l}\text { REGINALDO FELISBI- } \\
\text { NO }\end{array}$ & $\begin{array}{l}\mathrm{PTB}(\mathrm{PTB} / \mathrm{PMDB} / \\
\mathrm{PR} / \mathrm{PSB} / \mathrm{PSDB})\end{array}$ & 215 & 4,38 & Eleito por média \\
\hline $\begin{array}{l}\text { SEBASTIÃO MACHA- } \\
\text { DO DA SILVEIRA }\end{array}$ & DEM (PRB/DEM) & 166 & 3,38 & Eleito por QP \\
\hline $\begin{array}{l}\text { ANGELA MARIA DE } \\
\text { BARROS }\end{array}$ & $\mathrm{PT}$ (PT/PSC/PPS) & 129 & 2,63 & Eleito por QP \\
\hline
\end{tabular}

$\left({ }^{*}\right)$ Percentual sobre os votos válidos para o cargo no município

As quantidades de votos dos candidatos com registros pendentes no TSE não são apresentadas nesta consulta.

Atualizado em 11/01/2016 às 19:48

Fonte: Estatísticas e Resultado das Eleições TSE (2012)

Qual a finalidade, portanto, dessa alteração legislativa?

O Senado Federal divulgou, em 21/12/20015, notícia em seu sítio eletrônico informando sobre o fim da figura do "puxador de votos" a partir da reforma aprovada em 2015, ou seja, a Lei 13165, especificamente no tema tratado nesse estudo:

Outra inovação resultante da reforma política aprovada em 2015 é o fim da figura de puxador de votos nas eleições proporcionais (vereadores e deputados distritais, estaduais e federais). Não deve mais se repetir o que aconteceu em 2002, por exemplo, quando Enéas Carneiro foi o deputado federal mais bem votado no País. Os 1,5 milhão de votos do candidato do Prona foram suficientes para a diplomação de mais cinco candidatos. Um deles recebeu cera de 300 votos.

A lei determina agora que nas eleições de deputado e vereador, apenas serão elei- 
tos candidatos que obtiverem um mínimo de $10 \%$ do quociente eleitoral (total de votos válidos dividido pelas cadeiras em disputa) ${ }^{465}$.

Na mesma linha, o Tribunal Superior Eleitoral publicou a Série Reforma Eleitoral 2015, com informações sobre as alterações promovidas pela novel lei, esclarecendo, especificamente sobre o tema da distribuição das cadeiras no sistema proporcional:

\section{Cálculo dos eleitos no pleito proporcional}

(...)

Conforme explica o ministro Henrique Neves, no Brasil, os candidatos chamados de puxadores de votos, aqueles políticos que obtém uma votação mais expressiva, podem utilizar esses votos em favor do partido."Mas a pessoa que está sendo eleita pelo partido tem que ter o mínimo de representatividade popular e, por isso, se estabeleceu esses $10 \%$ ", afirma o ministro.

A partir do momento que se verifica quem são as pessoas que obtiveram esse quociente individual, ou seja, votos em número igual ou superior a $10 \%$ do quociente eleitoral, serão feitos os demais cálculos para se verificar a quais partidos serão destinadas as sobras. Segundo o parágrafo único do artigo 108, os lugares não preenchidos em razão da exigência da votação nominal mínima serão distribuídos de acordo com as novas regras do artigo $109^{466}$.

Ambos se referem aos chamados 'puxadores de votos' para justificar a alteração legislativa. A publicação da Agencia Senado cita, inclusive, o caso Enéas, de 2002. Exemplos mais recentes podem ser apontados, como a eleição (2010) e a reeleição (2014) do Deputado Tiririca. Passamos, portanto, à análise das eleições para o Cargo de Deputado Federal no Estado de São Paulo em 2014.

O Quadro 9 traz os dados gerais sobre o resultado das eleições para Deputado Federal em São Paulo, com o Quociente Eleitoral calculado naquela eleição - 303.803 - o que significaria dizer, à luz da nova legislação, que os candidatos precisariam obter, no mínimo, votação nominal correspondente à $10 \%$ desse valor, ou seja, 30.380 votos.

O Quadro 10 permite analisar se pela análise da votação nominal dos candidatos eleitos, considerando a novel lei nos resultados das Eleições de 2014, todos atenderiam as exigências legais.

465. Agência Senado 2015. Disponível em: <http://www12.senado.leg.br/noticias/materias/2015/12/21/ senado-votou-propostas-para-dar-mais-transparencia-as-eleicoes-e-reduzir-custos/tablet $>$. Acesso em: $11 / 01 / 2016$

466. Série reforma eleitoral, 2015 TSE. Disponível em: < http://www.tse.jus.br/imprensa/noticiastse/2015/Outubro/serie-reforma-eleitoral-2015-conheca-os-principais-pontos-alterados-no-codigo-eleitoral>. Acesso em: 11/01/2016. 
Quadro 9 - Eleições 2014 - Deputado Federal - SP

Eleição: Eleições Gerais 2014 - 1º Turno - 05/10/2014

Abrangência: UF - Cargo: Todos

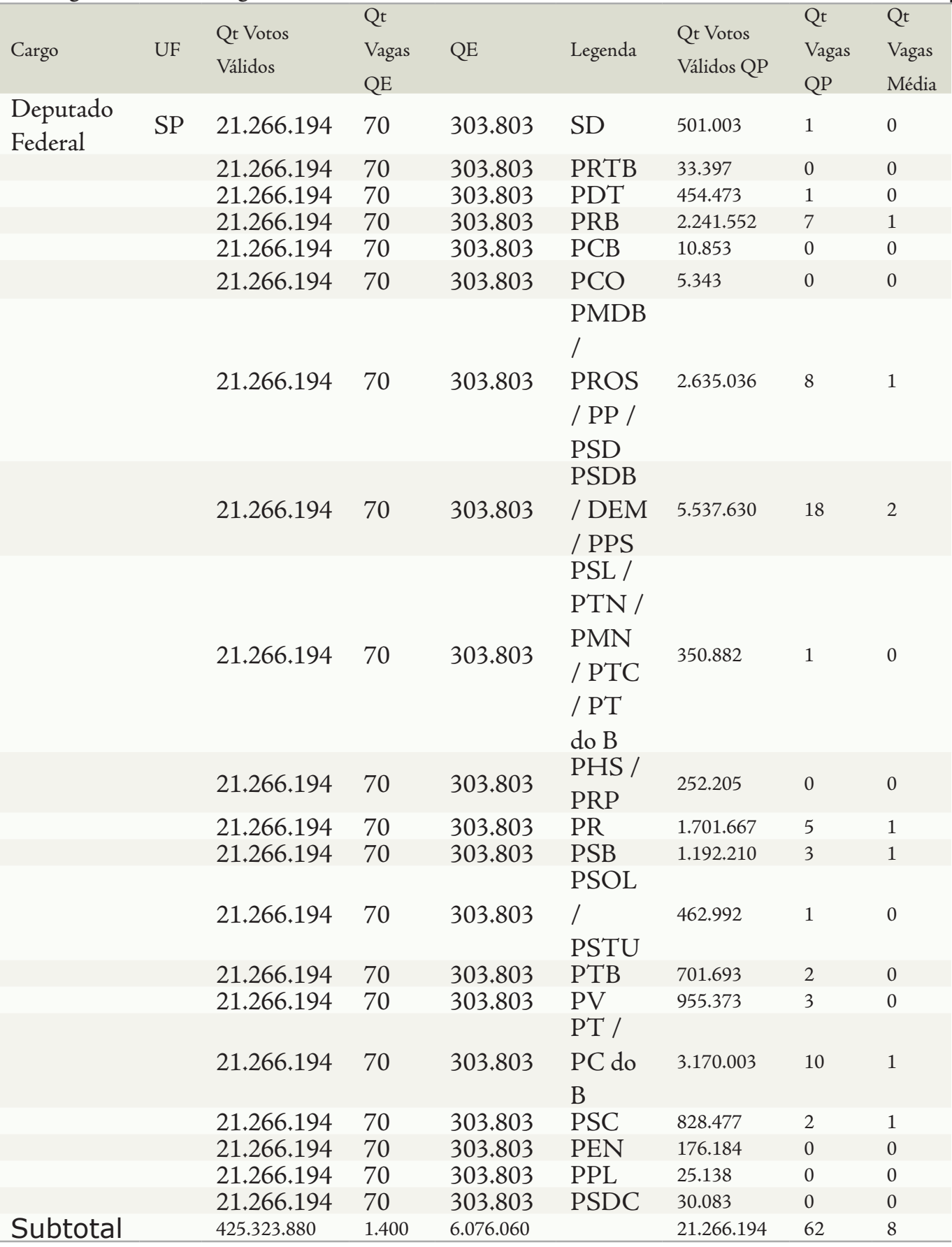

Fonte: TSE, 2014 
Quadro 10 - Eleições 2014 - Deputado Federal - SP - Votação nominal

\begin{tabular}{|c|c|c|c|}
\hline \multicolumn{4}{|l|}{ Eleição: Eleições Gerais 2014} \\
\hline \multicolumn{4}{|c|}{ Abrangência: UF SP - Cargo: Deputado Federal } \\
\hline Candidato & Partido & Coligação & Votação \\
\hline $\begin{array}{l}\text { CELSO UBIRAJARA } \\
\text { RUSSOMANNO }\end{array}$ & $\mathrm{PRB}$ & PRB & 1.524 .361 \\
\hline $\begin{array}{l}\text { FRANCISCO EVERARDO } \\
\text { OLIVEIRA SILVA }\end{array}$ & PR & $\mathrm{PR}$ & 1.016 .796 \\
\hline $\begin{array}{l}\text { MARCO ANTONIO } \\
\text { FELICIANO }\end{array}$ & PSC & PSC & 398.087 \\
\hline BRUNO COVAS LOPES & PSDB & PSDB / DEM / PPS & 352.708 \\
\hline RODRIGO GARCIA & DEM & PSDB / DEM / PPS & 336.151 \\
\hline $\begin{array}{l}\text { CARLOS HENRIQUE } \\
\text { FOCESI SAMPAIO }\end{array}$ & PSDB & PSDB / DEM / PPS & 295.623 \\
\hline $\begin{array}{l}\text { ANTONIO DUARTE } \\
\text { NOGUEIRA JUNIOR }\end{array}$ & PSDB & PSDB / DEM / PPS & 254.051 \\
\hline PAULO SALIM MALUF & $\mathrm{PP}$ & PMDB / PROS / PP / PSD & 250.296 \\
\hline $\begin{array}{l}\text { JOSÉ RICARDO } \\
\text { ALVARENGA TRIPOLI }\end{array}$ & PSDB & PSDB / DEM / PPS & 233.806 \\
\hline $\begin{array}{l}\text { SAMUEL MOREIRA } \\
\text { DA SILVA JUNIOR }\end{array}$ & PSDB & PSDB / DEM / PPS & 227.210 \\
\hline PAULO PEREIRA DA SILVA & $\mathrm{SD}$ & $\mathrm{SD}$ & 227.186 \\
\hline $\begin{array}{l}\text { LUIZ FELIPE BALEIA } \\
\text { TENUTO ROSSI }\end{array}$ & PMDB & PMDB / PROS / PP / PSD & 208.352 \\
\hline $\begin{array}{l}\text { EDUARDO PEDROSA } \\
\text { CURY }\end{array}$ & PSDB & PSDB / DEM / PPS & 185.638 \\
\hline $\begin{array}{l}\text { MARCIO LUIZ ALVINO } \\
\text { DE SOUZA }\end{array}$ & PR & $\mathrm{PR}$ & 179.950 \\
\hline SERGIO OLIMPIO GOMES & PDT & PDT & 179.196 \\
\hline JORGE TADEU MUDALEN & DEM & PSDB / DEM / PPS & 178.771 \\
\hline BRUNA DIAS FURLAN & PSDB & PSDB / DEM / PPS & 178.606 \\
\hline $\begin{array}{l}\text { LUIZA ERUNDINA } \\
\text { DE SOUSA }\end{array}$ & PSB & PSB & 177.279 \\
\hline VITOR LIPPI & PSDB & PSDB / DEM / PPS & 176.153 \\
\hline SILVIO FRANÇA TORRES & PSDB & PSDB / DEM / PPS & 175.310 \\
\hline $\begin{array}{l}\text { ANDRES NAVARRO } \\
\text { SANCHEZ }\end{array}$ & PT & $\mathrm{PT} / \mathrm{PC}$ do B & 169.834 \\
\hline IVAN VALENTE & PSOL & PSOL / PSTU & 168.928 \\
\hline $\begin{array}{l}\text { MIGUEL MOUBADDA } \\
\text { HADDAD }\end{array}$ & PSDB & PSDB / DEM / PPS & 168.278 \\
\hline ALEX SPINELLI MANENTE & PPS & PSDB / DEM / PPS & 164.760 \\
\hline
\end{tabular}




\begin{tabular}{|c|c|c|c|}
\hline $\begin{array}{l}\text { JEFFERSON ALVES DE } \\
\text { CAMPOS }\end{array}$ & PSD & PMDB / PROS / PP / PSD & 161.790 \\
\hline $\begin{array}{l}\text { GUILHERME MUSSI } \\
\text { FERREIRA }\end{array}$ & $\mathrm{PP}$ & PMDB / PROS / PP / PSD & 156.297 \\
\hline $\begin{array}{l}\text { ARNALDO CALIL } \\
\text { PEREIRA JARDIM }\end{array}$ & PPS & PSDB / DEM / PPS & 155.278 \\
\hline $\begin{array}{l}\text { MARA CRISTINA } \\
\text { GABRILLI }\end{array}$ & PSDB & PSDB / DEM / PPS & 155.143 \\
\hline $\begin{array}{l}\text { JOSE OLÍMPIO SILVEIRA } \\
\text { MORAES }\end{array}$ & $\mathrm{PP}$ & PMDB / PROS / PP / PSD & 154.597 \\
\hline VANDERLEI MACRIS & PSDB & PSDB / DEM / PPS & 148.449 \\
\hline $\begin{array}{l}\text { CARLOS ALBERTO ROLIM } \\
\text { ZARATTINI }\end{array}$ & $\mathrm{PT}$ & PT / PC do B & 138.286 \\
\hline $\begin{array}{l}\text { ANTONIO CARLOS } \\
\text { MARTINS DE BULHÕES } \\
\end{array}$ & PRB & PRB & 137.939 \\
\hline $\begin{array}{l}\text { ARLINDO CHIGNALIA } \\
\text { JUNIOR }\end{array}$ & PT & PT / PC do B & 135.772 \\
\hline ADRIANO ELI CORREA & DEM & PSDB / DEM / PPS & 134.138 \\
\hline $\begin{array}{l}\text { BENEDITO ROBERTO } \\
\text { ALVES FERREIRA }\end{array}$ & PRB & PRB & 130.516 \\
\hline $\begin{array}{l}\text { ANA LUCIA LIPPAUS } \\
\text { PERUGINI }\end{array}$ & PT & $\mathrm{PT} / \mathrm{PC}$ do B & 121.681 \\
\hline $\begin{array}{l}\text { GILBERTO NASCIMENTO } \\
\text { SILVA }\end{array}$ & PSC & PSC & 120.044 \\
\hline $\begin{array}{l}\text { VICENTE CANDIDO } \\
\text { DA SILVA }\end{array}$ & $\mathrm{PT}$ & $\mathrm{PT} / \mathrm{PC}$ do B & 117.652 \\
\hline $\begin{array}{l}\text { JOAO PAULO TAVARES } \\
\text { PAPA }\end{array}$ & $\mathrm{PSDB}$ & PSDB / DEM / PPS & 117.590 \\
\hline $\begin{array}{l}\text { MILTON ANTONIO } \\
\text { CASQUEL MONTI } \\
\end{array}$ & $\mathrm{PR}$ & $\mathrm{PR}$ & 115.942 \\
\hline $\begin{array}{l}\text { ANTONIO FLORIANO } \\
\text { PEREIRA PESARO } \\
\end{array}$ & PSDB & PSDB / DEM / PPS & 113.949 \\
\hline RICARDO IZAR JUNIOR & PSD & PMDB / PROS / PP / PSD & 113.547 \\
\hline ARNALDO FARIA DE SÁ & PTB & PTB & 112.940 \\
\hline $\begin{array}{l}\text { EDSON EDINHO COELHO } \\
\text { ARAUJO }\end{array}$ & PMDB & PMDB / PROS / PP / PSD & 112.780 \\
\hline NELSON MARQUEZELLI & PTB & PTB & 112.711 \\
\hline $\begin{array}{l}\text { LUIZ PAULO TEIXEIRA } \\
\text { FERREIRA }\end{array}$ & $\mathrm{PT}$ & PT / PC do B & 111.301 \\
\hline $\begin{array}{l}\text { PAULO ROBERTO FREIRE } \\
\text { DA COSTA }\end{array}$ & $\mathrm{PR}$ & $\mathrm{PR}$ & 111.300 \\
\hline
\end{tabular}




\begin{tabular}{|c|c|c|c|}
\hline $\begin{array}{l}\text { ALEXANDRE LEITE } \\
\text { DA SILVA }\end{array}$ & DEM & PSDB / DEM / PPS & 109.708 \\
\hline $\begin{array}{l}\text { EVANDRO HERRERA } \\
\text { BERTONE GUSSI }\end{array}$ & PV & $\mathrm{PV}$ & 109.591 \\
\hline $\begin{array}{l}\text { LUIZ LAURO FERREIRA } \\
\text { FILHO }\end{array}$ & PSB & PSB & 105.247 \\
\hline $\begin{array}{l}\text { IOLANDA KEIKO } \\
\text { MIASHIRO OTA }\end{array}$ & PSB & PSB & 102.963 \\
\hline NILTO IGNÁCIO TATTO & $\mathrm{PT}$ & $\mathrm{PT} / \mathrm{PC}$ do B & 101.196 \\
\hline $\begin{array}{l}\text { HERCULANO CASTILHO } \\
\text { PASSOS JUNIOR }\end{array}$ & PSD & PMDB / PROS / PP / PSD & 92.583 \\
\hline $\begin{array}{l}\text { ANTONIO GOULART } \\
\text { DOS REIS }\end{array}$ & PSD & PMDB / PROS / PP / PSD & 92.546 \\
\hline $\begin{array}{l}\text { ORLANDO SILVA DE JESUS } \\
\text { JUNIOR }\end{array}$ & $\mathrm{PCdoB}$ & $\mathrm{PT} / \mathrm{PC}$ do B & 90.641 \\
\hline $\begin{array}{l}\text { FLAVIO AUGUSTO } \\
\text { DA SILVA }\end{array}$ & PSB & PSB & 90.437 \\
\hline VICENTE PAULO DA SILVA & $\mathrm{PT}$ & $\mathrm{PT} / \mathrm{PC}$ do B & 89.001 \\
\hline $\begin{array}{l}\text { RENATA HELLMEISTER } \\
\text { DE ABREU }\end{array}$ & PTN & $\begin{array}{l}\text { PSL / PTN / PMN / PTC / } \\
\text { PT do B }\end{array}$ & 86.647 \\
\hline VALMIR PRASCIDELLI & $\mathrm{PT}$ & $\mathrm{PT} / \mathrm{PC}$ do B & 84.419 \\
\hline $\begin{array}{l}\text { JOSE MENTOR GUILHERME } \\
\text { DE MELLO NETTO }\end{array}$ & $\mathrm{PT}$ & $\mathrm{PT} / \mathrm{PC}$ do B & 82.368 \\
\hline $\begin{array}{l}\text { EDUARDO NANTES } \\
\text { BOLSONARO }\end{array}$ & PSC & PSC & 82.224 \\
\hline $\begin{array}{l}\text { VINICIUS RAPOZO } \\
\text { DE CARVALHO }\end{array}$ & PRB & PRB & 80.643 \\
\hline $\begin{array}{l}\text { ROBERTO ALVES } \\
\text { DE LUCENA }\end{array}$ & PV & PV & 67.191 \\
\hline $\begin{array}{l}\text { SINVAL MALHEIROS } \\
\text { PINTO JUNIOR }\end{array}$ & PV & $\mathrm{PV}$ & 59.362 \\
\hline JOSE AUGUSTO ROSA & $\mathrm{PR}$ & $\mathrm{PR}$ & 46.905 \\
\hline SERGIO BAVINI & PRB & PRB & 45.330 \\
\hline MIGUEL LOMBARDI & $\mathrm{PR}$ & $\mathrm{PR}$ & 32.080 \\
\hline $\begin{array}{l}\text { PAULO ROBERTO } \\
\text { GOMES MANSUR }\end{array}$ & PRB & PRB & 31.301 \\
\hline MARCELO SQUASSONI & $\mathrm{PRB}$ & $\mathrm{PRB}$ & 30.315 \\
\hline FAUSTO RUY PINATO & $\mathrm{PRB}$ & PRB & 22.097 \\
\hline
\end{tabular}

Fonte: TSE, 2014 
Francisco Everardo Oliveira Silva - PR (Tiririca) foi o segundo Deputado Federal com maior votação nominal do Estado de São Paulo, atrás, apenas, de Celso Russomano - PRB. É possível observar que, entre os 70 Deputados Federais eleitos em 2014, apenas dois não teriam atingido o mínimo de votação nominal (30.380 votos): Marcelo Squassoni e Fausto Ruy Pinato, ambos do PRB.

Embora se fale em "efeito Tiririca", nas eleiçóes de 2014 o candidato "puxador de votos" foi Celso Russomano, do PRB, que naquele pleito elegeu oito Deputados disputando isoladamente as eleiçóes. Veja-se, no Quadro 10, que o PRB obteve 2.241.552 votos no total, dos quais, 1.524.361 foram nominativos ao então candidato Celso Russomano. Os votos nominais do candidato representaram, naquela eleição, nada menos que $68 \%$ do total dos votos do seu partido - PRB.

Apesar de impressionarem, esses dados mostram que apenas dois, de 70 candidatos eleitos não atingiriam o mínimo legal exigido - num primeiro momento, repita-se. Além disso, importa destacar que no caso em análise, os candidatos eleitos obtiveram votação nominal próxima do mínimo exigido. É dizer, a alteração legislativa, aparentemente, não gera grandes impactos diretos no resultado das eleições proporcionais, no que concerne à definição de quantidades mínimas de votação nominal, eis que, conforme observado nos Quadros 4 e 5, há uma maior tendência de votação nominal pelo eleitorado brasileiro ${ }^{467}$.

Por outro lado, a alteração do cálculo da distribuição das vagas remanescentes com o estabelecimento de divisor fixo para os partidos (art. 109, I, CE) pode provocar maiores distorções. É dizer, se adotado o sistema de maiores médias - o que teoricamente não foi alterado pela Minirreforma de 2015, pois o próprio dispositivo faz menção expressa à maior média - não há sentido em repetir os cálculos se não haverá variação no número de vagas obtidas.

É o que se pode perceber da análise do Quadro 9, por exemplo. Das 70 vagas em disputa no pleito de 2014 para o cargo de Deputado Federal em São Paulo, 62 foram distribuídas pelo quociente partidário, e 8 por maiores médias, ou seja, distribuição das sobras. Essas oito cadeiras foram distribuídas para sete partidos diferentes, pois a cada vez que o cálculo era repetido, o divisor do partido beneficiado por uma vaga era alterado, modificando, portando, a sua média final. Se o divisor fosse sempre o mesmo, as oito vagas em questão iriam para um mesmo partido, pois a média seria sempre a mesma.

Veja-se. Antes da reforma, o art. 109, I, estabelecia a obrigatoriedade de "dividir-se-á o número de votos válidos atribuídos a cada Partido ou coligação de Partidos pelo número de lugares por ele obtido, mais um". Sempre que o partido fosse beneficiado com uma nova vaga, esse divisor, referente ao número de lugares por ele obtido, seria modificado.

Após a reforma, o dispositivo em questão passa a prever que "dividir-se-á o número de votos válidos atribuídos a cada partido ou coligação pelo número de lugares definido para o partido pelo cálculo do quociente partidário do art. 107, mais um". O número de lugares obtido pelo cálculo do quociente partidário é invariável. $\mathrm{O}$ resultado da divisão com divisor e dividendo idênticos, somente poderá ser o mesmo, quantas vezes for repetido. Esse, precisamente, o ponto suscitado como inconstitucional pelo Procurador Geral da República por meio da ADI 5420 em relação ao qual se obteve medida cautelar para suspender a alteração legislativa promovida pela Lei 13165/2015 sobre o art. 109 do Código Eleitoral.

467. Sobre o tema, sugere-se a leitura do artigo "Anacronismo do sistema proporcional de lista aberta no Brasil - Ocaso das razões originárias de sua adoção” (PEREIRA; GELAPE, 2015), que entre outros pontos, destaca o "voto natural" do brasileiro, o voto uninominal, para um determinado candidato. 


\section{Conclusão}

A Lei 13165/2015 promoveu diversas alterações no Código Eleitoral, na Lei das Eleições (9504/97) e Lei dos Partidos Políticos (9096/95). Dentre as modificações, está a alteração na distribuição das cadeiras no sistema proporcional brasileiro por meio da fixação de um indicador mínimo de votação nominal para distribuição das vagas (obtidas por quociente partidário e as remanescentes) e de modificação na distribuição das vagas remanescentes com a adoção de divisor fixo.

Essa modificação legislativa, embora promovida em momento político favorável em virtude das pressões sofridas pelas manifestações populares de 2013, não representou uma Reforma Política significativa, senão que manteve o padrão já verificado de pequenas alterações pontuais na legislação eleitoral. Com a aparente urgência na promulgação da Lei 13165/2015 para que pudesse ser aplicada nas eleições municipais de 2016 (desde publicada pelo menos um ano antes do pleito), a lei apresenta algumas inconsistências.

A revisão do sistema proporcional brasileiro é uma das pautas de reforma política há muito tempo, seja para modificação na forma de apresentação de listas, proibição de coligação, ou em relação à mudança do próprio sistema. Esses temas estão sendo discutidos, entre outros, pelo Congresso Nacional em Projetos de Emenda da Constituição. No entanto, as alteraçóes da Lei 13652/2015, no que diz respeito ao sistema eleitoral, não parecem ter promovido melhoras.

Entre as maiores críticas ao sistema proporcional brasileiro, está a forma com que institutos políticos aparentemente divergentes são inseridos num mesmo contexto de distribuição de cadeiras legislativas para pautar a disputa eleitoral. A soma, no sistema proporcional brasileiro, da lista aberta com possibilidade de votação nominal ou de legenda ${ }^{468}$, de autonomia dos partidos para se coligarem sem obrigatoriedade de verticalização, da ausência de critérios para assegurar a proporcionalidade da representação no âmbito da coligação, somados à nova exigência de votação nominal mínimo - que pode implicar em perda de representação para o partido que não tenha candidatos com votação nominal mínima exigida -, criam uma complicada realidade: interferem na capacidade ${ }^{469}$ de escolha do eleitor. $\mathrm{O}$ eleitor mais consciente e interessado não tem condições de definir se seu voto irá, de fato, auxiliar a eleição de um candidato de sua preferência, nem mesmo de seu partido.

A introdução da exigência de votação nominal mínima para os candidatos no sistema proporcional desconsidera a possibilidade/representatividade do voto de legenda - que existe no Brasil, embora utilizada pelo eleitorado em menor proporção - e cria a possibilidade de distorção do resultado na medida em que possibilita a perda de vagas obtidas por partidos ou coligações em virtude de um indicador de votação nominal - que sequer é regra em nosso sistema.

468. A legenda, no caso, será sempre do partido, independentemente de ele ter se coligado, pois coligação não possui legenda própria. Uma vez que seja formada coligação, os votos de legenda dos partidos coligados serão somados para fins de definição de quociente eleitoral e partidário, independente do percentual de votos atribuídos a cada partido.

469. A escolha do termo 'capacidadé não é casual, nem se refere à capacidade intelectual, civil ou consciência política do eleitor. $\mathrm{O}$ que se pretende destacar com a expressão é que nem mesmo o eleitor mais consciente, informado, comprometido com sua participação política tem condições de assegurar que seu voto seja dirigido ao partido de sua pretensão. Pensando em votar no partido X que compõe a coligação formada por $\mathrm{x}, \mathrm{y}$, w e z, o voto do eleitor pode redundar na eleição de um candidato de qualquer dos outros partidos - que inclusive podem contem plataforma política totalmente distinta de suas convicções políticas. 
É dizer, se um partido obteve 10 vagas na distribuição do quociente partidário, mas somente 8 de seus candidatos possuem a votação nominal mínima, o partido perde essas outras duas vagas, que serão redistribuídas entre todos os partidos/coligações que tenham atingido o quociente eleitoral. A distorção no direcionamento do voto que antes ficaria restrita aos partidos integrantes da coligação, agora pode atingir todos os demais partidos que atingirem o quociente eleitoral.

Antes da modificação promovida pela Lei 13165/2015 essa distorção poderia ser evitada não votando em partidos coligados - independentemente de o voto ser nominal ou de legenda, pois num primeiro momento, para cálculo do quociente eleitoral e partidário todos os votos são somados. Após a modificação legislativa que estabelece o percentual mínimo de votos nominais, somado à possibilidade de o partido perder cadeiras se não tiver candidatos com votação nominal mínima, não há mais garantias nesse sentido. É dizer, ainda que o eleitor opte por votar em algum candidato de partido não coligado - ou na legenda, aqui não haverá diferença - esse voto pode ser redirecionado para qualquer partido que tenha atingido o quociente eleitoral, quando houver a redistribuição das vagas remanescentes.

Ainda que, percentualmente, essa alteração possa não gerar impacto significativo, ela interfere na participação do eleitor, por meio do voto, e via de consequência, na realização do accontability vertical, como apontado anteriormente. Ademais, é possível que se verifique, nas eleiçóes vindouras, um agravamento da disputa entre candidatos de um mesmo partido. Este é, sem dúvidas, um efeito do voto nominal que já era marca no sistema proporcional brasileiro, mas que se tende a aumentar na medida em que a alteração legislativa traz um maior peso a essa votação nominal - como critério para ocupação de vagas pelos partidos políticos.

Já com relação à alteração no cálculo da distribuição das sobras com um divisor fixo a distorção e a violação ao sistema proporcional ficam ainda mais evidentes, e neste caso, a alteração poderia gerar um grande impacto no resultado nas eleições. Isto porque, conforme se demostrou, com a adoção de um divisor fixo, sempre que fossem distribuídas as vagas remanescentes, não importa quantas vezes fosse refeito o cálculo, o resultado seria sempre o mesmo, e todas as vagas remanescentes seriam destinadas ao mesmo partido/coligação.

O sistema proporcional, assim como qualquer outro, possui uma gama de elementos, características, normas, regras e fórmulas. Vários países no mundo adotam o sistema proporcional, e o fazem das mais diversas formas. Se os "sistemas proporcionais procuram garantir uma equidade matemática entre os votos e as cadeiras dos partidos ${ }^{470}$ que disputaram uma eleição", como esclarece Jairo Nicolau ${ }^{471}$ (2004, p. 37), a compreensão do sistema proporcional estaria relacionada a uma representação partidária e a inovação legislativa representaria violação à representação proporcional.

O Glossário contido na obra de Michael Gallagher e Paul Mitchell, "The Politics of Electoral Systems" traz um conceito mais amplo de representação proporcional, sem vincular a compreensão do princípio a instituições politicas, como partidos, mas somente ao voto: "the principle that the distribuition of seats should be closely resembly the distribuition of votes. this broad principle can be given effect by a large number of specific PR electoral systems ${ }^{472}$."

470. Sobre a importância do papel dos partidos políticos e sua modificação ao longo do tempo, indica-se a leitura do artigo "Os partidos políticos e a democracia", de Peter Mair e Rui Cabral (2003).

471. NICOLAU, Jairo Marconi. Sistemas eleitorais. EDITORA FGV, 2004, p. 37.

472. GALLAGHER, Michael; MITCHELL, Paul (Ed.). The politics of electoral systems. Oxford: Oxford University Press, 2005, p. 634. 
Independentemente de considerar se há violação ao sistema proporcional ou não, verifica-se, na verdade, que são os arranjos institucionais inconsistentes entre si que dificultam a participação política por meio do voto, seja em virtude da ausência de compreensão do sistema, seja em virtude do descrédito do processo democrático. Da mesma forma e pela mesma razão, dificultam o accountability vertical pelos eleitores no sistema proporcional.

Desse modo, considerando-se as alterações promovidas pela Lei 13165/2015 aos dispositivos que tratam da distribuição das vagas nas eleições proporcionais à luz dos indicativos de qualidade da democracia apresentados por Diamond e Morlino, tem-se que a inovação é prejudicial à qualidade de nossa democracia. Isso porque afeta, de forma direta, as dimensóes de participação e accountability vertical.

\section{Referências}

BONAVIDES, Paulo. Ciência política. São Paulo: Malheiros, 2012.

CAMPOS, Adriana; NETTO, Felipe Peixoto Braga; SANTOS, Polianna. Democracia e Sufrágio: sobre a necessária compreensão dos sistemas eleitorais brasileiros. In: Maria Fernanda Salcedo Repolês; Maria Tereza Fonseca Dias. (Org.). O Direito entre a esfera pública e a autonomia privada: transformações do direito público no ambiente democrático. 1ed. Belo Horizonte: Editora Fórum, 2015, v. 2, p. 91-105.

CAMPOS, Adriana; SANTOS, Polianna. Democracia, direitos políticos e sistema proporcional brasileiro: reflexões sobre a adoção de cálculo intracoligacional. In: Jonathan Barros Vita; Jamile Bergamaschini Mata Diz; Narciso Leandro Xavier Baez. (Org.). Direitos Fundamentais e Democracia III. 1ed.Florianópolis: CONPEDI, 2014, v. III, p. 357-377. Disponível em: < http://publicadireito.com.br/artigos/?cod=8cec19a74549d78a >. Acesso em: $27 / 10 / 2015$.

CAMPOS, Adriana; SANTOS, Polianna; STUDART, P. H. M.. Partidos Políticos, Coligações e Blocos de Atuação nas Casas Legislativas: O Congresso Nacional Brasileiro. In: VIII Congresso Latinoamericano de Ciência Política - ALACIP, 2015, Lima, Peru. Anales de VIII Congreso Latinoamericano de Ciencia Política ALACIP, 2015. v. I. p. 11-38. Disponível em: $<$ http://congreso.pucp.edu.pe/alacip2015/ponencias/?pagina=12>. Acesso em 27/10/2015.

DAHL, Robert A.: tradução de Beatriz Sidou. Sobre a democracia. Brasília: Editora Universidade de Brasília, 2001.

DIAMOND, Larry; MORLINO, Leonardo. The Quality of Democracy. CDDRL Working Papers, page 37. 2004. Disponível em: < http://cddrl.fsi.stanford.edu/publications/the _ quality_of_democracy $>$. Acesso em: 04/01/2016.

FABRE, Simone Goyard. O que é democracia. São Pauloः Martins Fontes, 2003, 
GALLAGHER, Michael; MITCHELL, Paul (Ed.). The politics of electoral systems. Oxford: Oxford University Press, 2005.

JORGE, Bernardo Wahl G. de Araújo. "Brasil, Manifestações Populares e Grandes Eventos: Questões de (In)Segurança e Imagem Internacional. Revista Mundorama, 2013. Disponível em: http://www.mundorama.net/2013/06/22/brasil-manifestacoes-populares-e-grandeseventos-questoes-de-inseguranca-e-imagem-internacional-por-bernardo-wahl-g-de-araujojorge/. Acesso em: 10/01/2016.

MAIR, Peter; CABRAL, Rui. Os partidos políticos e a democracia. Análise Social. p. 277 293, 2003.

MELO, Carlos Ranulfo. Reforma Política em Perspectiva Comparada na América do Sul. p. 45-62. In. AVRITZER, Leonardo; ANASTASIA, Fátima (Ed.). Reforma política no Brasil. Editora UFMG, 2007.

NICOLAU, Jairo Marconi. Sistemas eleitorais. EDITORA FGV, 2004.

O’DONELL, Guillermo A. Delegative democracy. Journal of democracy, v. 5, n. 1, p. 55-69, 1994.

PATEMAN, Carole. Participação e teoria democrática. Paz e Terra, 2003,

PEREIRA, Rodolfo Viana. GELAPE, Lucas de Oliveira. Anacronismo do sistema proporcional de lista aberta no Brasil. Revista de informação legislativa, v. 52, n. 205, p. 261-279, jan./mar. 2015. Disponível em: <http://www2.senado.gov.br/bdsf/item/id/509952>. Acesso em: 26/10/2015.

RAMOS, Paola Novaes. Alheamento eleitoral: reflexões sobre o significado de votos embranco, votos nulos e abstenções na teoria política contemporânea. Mediações-Revista de Ciências Sociais, v. 14, n. 1, p. 170-199, 2009. Available in: <http://www.uel.br/revistas/uel/index. $\mathrm{php} /$ mediacoes/article/view/3356>. Access on: 04.19.2015

SALGADO, Eneida Desiree. Sistemas Eleitorais: experiências iberoamericanas e características do modelo brasileiro. Coordenadora Eneida Desiree Salgado. Belo Horizonte: Fórum, 2012.

SILVA, Luis Virgílio Afonso da. Sistemas eleitorais: tipos, efeitos jurídico-políticos e aplicação ao caso brasileiro. São Paulo: Malheiros, 1999.

TAVARES, José Antônio Giusti. Sistemas Eleitorais nas Democracias Contemporâneas.Teoria, instituições, estratégia. Rio de Janeiro: Relume-Dumará, 1994. 


\section{LEGISLAÇÃO, JURISPRUDÊNCIA E BANCOS DE DADOS}

BRASIL. Código Eleitoral. Brasília: Presidência da República, Casa Civil, 2013. Disponível em: < http://www.planalto.gov.br/ccivil_03/leis/14737.htm>. Acesso em 06/01/2016

BRASIL. Constituição da República Federativa do Brasil de 1988. Brasília: Presidência da República, Casa Civil, 2012. Disponível em: <http://www.planalto.gov.br >. Acesso em 06/01/2016

BRASIL. Câmara dos Deputados. Projetos de Leis e outras Proposições. Disponível em: $<$ http://www2,camara.leg.br/proposicoesWeb/prop_emendas;jsessionid=0E17BF9F7B26C75690B768C58D337BED. proposicoesWeb2?idProposicao $=580148 \&$ subst $=0>$. Acesso em 10/01/2016.

BRASIL. Câmara dos deputados. Câmara, Notícias 2005. Disponível em: <http://www2. camara.leg.br/camaranoticias/noticias/70183.html>. Acesso em: 10/01/2016.

BRASIL. Palácio do Planalto, Presidência da República. Disponível em: http://www2.planalto.gov.br/acompanhe-o-planalto/discursos/discursos-dapresidenta/pronunciamento-da-presidenta-da-republica-dilma-rousseff-em-cadeia-nacional-de-radio-e-tv. Acesso em: 10/01/2016.

BRASIL. Senado Federal. Agência Senado 2015. Disponível em: < http://www12.senado. leg.br/noticias/materias/2015/12/21/senado-votou-propostas-para-dar-mais-transparencia-as-eleicoes-e-reduzir-custos/tablet $>$. Acesso em: 11/01/2016.

BRASIL. Supremo Tribunal Federal. ADI 5420. Disponível em: <http://www.stf.jus.br/ portal $/$ geral $/$ verPdfPaginado. asp $?$ id $=9853482 \&$ tipo $=$ TP $\&$ descricao $=A D I \% 2 F 5420>$. Acesso em 11/01/2016.

BRASIL. Supremo Tribunal Federal. ADI 5420. Acompanhamento Processual. Disponível em: <http://www.stf.jus.br/portal/processo/verProcessoAndamento.asp?incidente= 4891075.>. Acesso em: 11/01/2016.

BRASIL. Tribunal Superior Eleitoral. Estatísticas Eleições 2012. Disponível em: http:// www.tse.jus.br/eleicoes/estatisticas/estatisticas-eleicoes-2012. Acesso em: 11/01/2016.

BRASIL. Tribunal Superior Eleitoral. Série reforma eleitoral 2015. Disponível em: < http:// www.tse.jus.br/imprensa/noticias-tse/2015/Outubro/serie-reforma-eleitoral-2015-conheca-os-principais-pontos-alterados-no-codigo-eleitoral >. Acesso em: 11/01/2016.

BRASIL. Tribunal Superior Eleitoral. Estatísticas Eleições 2012. Disponível em: <http:// www.tse.jus.br/eleicoes/estatisticas/estatisticas-eleitorais-2014-resultado.>. Acesso em $11 / 01 / 2016$. 
Recebido em: 19/01/2016

Aceito em: 23/03/2016

\section{Como citar}

SANTOS, Polianna. Sistema Proporcional Brasileiro e Lei 13165/2015:

Um breve estudo sob o prisma da Qualidade da Democracia. Ballot. Rio

de Janeiro: UERJ. Volume 2 Número 1 Janeiro/Abril 2016. pp. 245-285.

Disponível em: [http://www.e-publicacoes.uerj.br/index.php/ballot]

\section{(c) (1) $\$(0)$}

A Revista Ballot está licenciada sob uma licença Creative Commons Atribuição - Não Comercial - Compartilha Igual 3.0 Não Adaptada. 